\title{
Liquid Biopsy for Cancer Cachexia: Focus on Muscle-Derived microRNAs
}

\author{
Roberta Belli ${ }^{1, *,+}$, Elisabetta Ferraro ${ }^{2,+}{ }^{\text {, Alessio Molfino }}{ }^{1}$, Raffaella Carletti ${ }^{1}$, Federica Tambaro ${ }^{1}$, Paola Costelli ${ }^{3}$ \\ and Maurizio Muscaritoli ${ }^{1, *}$ \\ 1 Department of Translational and Precision Medicine, Sapienza University, 00185 Rome, Italy; \\ alessio.molfino@uniroma1.it (A.M.); raffaella.carletti@uniroma1.it (R.C.); federica.tambaro@uniroma1.it (F.T.) \\ 2 Unit of Cell and Developmental Biology, Department of Biology, University of Pisa, 56126 Pisa, Italy; \\ elisabetta.ferraro@unipi.it \\ 3 Department of Clinical and Biological Sciences, University of Torino, 10124 Torino, Italy; \\ paola.costelli@unito.it \\ * Correspondence: roberta.belli@uniroma1.it (R.B.); maurizio.muscaritoli@uniroma1.it (M.M.); \\ Tel./Fax: +390-649-972-020 (M.M.) \\ + These authors contributed equally to this work.
}

Citation: Belli, R.; Ferraro, E.; Molfino, A.; Carletti, R.; Tambaro, F.; Costelli, P.; Muscaritoli, M. Liquid Biopsy for Cancer Cachexia: Focus on Muscle-Derived microRNAs. Int. J. Mol. Sci. 2021, 22, 9007. https://doi.org/10.3390/ijms22169007

Academic Editor: Marta Murgia

Received: 5 July 2021

Accepted: 18 August 2021

Published: 20 August 2021

Publisher's Note: MDPI stays neutral with regard to jurisdictional claims in published maps and institutional affiliations.

Copyright: (c) 2021 by the authors. Licensee MDPI, Basel, Switzerland. This article is an open access article distributed under the terms and conditions of the Creative Commons Attribution (CC BY) license (https:/ / creativecommons.org/licenses/by/ $4.0 /)$.
Abstract: Cancer cachexia displays a complex nature in which systemic inflammation, impaired energy metabolism, loss of muscle and adipose tissues result in unintentional body weight loss. Cachectic patients have a poor prognosis and the presence of cachexia reduces the tolerability of chemo/radio-therapy treatments and it is frequently the primary cause of death in advanced cancer patients. Early detection of this condition could make treatments more effective. However, early diagnostic biomarkers of cachexia are currently lacking. In recent years, although solid biopsy still remains the "gold standard" for diagnosis of cancer, liquid biopsy is gaining increasing interest as a source of easily accessible potential biomarkers. Moreover, the growing interest in circulating microRNAs (miRNAs), has made these molecules attractive for the diagnosis of several diseases, including cancer. Some muscle-derived circulating miRNA might play a pivotal role in the onset/progression of cancer cachexia. This topic is of great interest since circulating miRNAs might be easily detectable by means of liquid biopsies and might allow an early diagnosis of this syndrome. We here summarize the current knowledge on circulating muscular miRNAs involved in muscle atrophy, since they might represent easily accessible and promising biomarkers of cachexia.

Keywords: cancer cachexia; liquid biopsy; miRNAs; biomarkers

\section{Introduction}

Cachexia is a multifactorial disorder associated with chronic diseases, such as cancer, chronic heart failure, chronic obstructive pulmonary disease, and chronic kidney disease [1].

Cachexia in cancer affects about half of the patients and is the direct cause of death in about $20 \%$ of them [2-7]. Cancer cachexia (CC) is a life-threatening disorder driven by a complex interaction between tumor-and host-related factors [8-10] and its underlying mechanisms are not completely clarified [11]. A major hallmark of cachexia is the involuntary weight loss due to low muscle mass, with or without loss of fat mass [12]. The pathophysiology of muscle wasting during cachexia is characterized by a negative protein and energy balance, caused by a variable combination of reduced food intake and metabolic abnormalities [13-15]. Chronic inflammation seems to be one of the major drivers of muscle wasting in cancer cachexia [16-18]. Also, altered glucose metabolism and insulin resistance are associated with cancer cachexia and their contribution to the progression of skeletal muscle wasting has been reviewed by Masi and collaborators [16-18]. In spite of its detrimental influence on patients' quality of life [8-10], morbidity and mortality, and the wide circulation of the diagnostic criteria [17], CC is still largely unrecognized, underdiagnosed and undertreated [19]. Currently no biomarkers of cancer cachexia are present [20]. 
In the last ten years, several molecules have been proposed as biomarkers of cachexia including pro-inflammatory cytokines (e.g., interleukine 6, IL-6 and tumor necrosis factor alpha, TNF- $\alpha$ ), hormones (e.g., leptin and ghrelin) and peptides such as C-terminal agrin fragment (CAF) [21-23]. However, none of these are specific to this syndrome and none of these fully satisfy the characteristics of a good biomarker in CC [21-23].

It has been suggested that some cellular mediators, including specific microRNAs (miRNAs), released by host tissues or by tumor cells, might contribute to the development of cachexia [23-25]. Detection of muscle-derived miRNAs in the blood might allow for the recognition of muscle derangements occurring in cachexia from the early stage.

In this review, we report on the most recent evidence on the modulation of circulating muscle-derived miRNAs during cancer cachexia, both in animal models and humans. We consider muscle-derived miRNAs those expressed- exclusively or not- by skeletal muscles. We hypothesize that, in the near future, the circulating forms of some of these miRNAs could be exploited as biomarkers of cancer cachexia in liquid biopsies.

\section{Liquid Biopsy}

\subsection{Liquid Biopsy in Cancer}

Liquid biopsy is a technique that is gaining increasing interest, especially in the field of oncology. Although solid biopsy still remains the "gold standard" for diagnosis and treatment choice for many types of cancer [26], liquid biopsy utilizes body fluids as surrogate tissues to provide information on cancer.

Originally, the liquid biopsy in the field of cancer was used to study mainly the circulating tumor cells (CTCs). Indeed, the U.S. National Cancer Institute (NCI) defined liquid biopsy as "a test done on a sample of blood to look for cancer cells from a tumor that are circulating in the blood or for pieces of DNA from tumor cells that are in the blood" [27]. However, in the last few years, besides CTCs, numerous circulating elements have been identified in liquid biopsies [28], such as cell-free circulating nucleic acids (cfNAs), microvesicles, and exosomes [29]. More schematically, in a liquid biopsy, we can non-invasively detect circulating cellular (i.e., CTCs), subcellular (extracellular vesicles) and molecular (e.g., DNA, miRNA, IncRNA, mRNA, proteins) [30,31] elements deriving from a tumor, which might allow the detection of tumor-specific genetic aberration, or RNA or protein alterations [30].

The detection and isolation of these circulating particles as sources of cancer genomic and proteomic information is commonly performed using blood samples [29]. However, CTCs, cfNAs and extracellular vesicles are also present in other biological fluids such as urine, saliva and cerebrospinal-fluid [32-38].

The scientific community's growing interest in liquid biopsy depends on the possibility to obtain relevant information on the tumor and to learn about its molecular dynamic changes with minimally invasive methods, less dangerous and less expensive compared to surgical biopsies [39-45]. Indeed, although giving direct information, tissue biopsies have some disadvantages such as lack of indications regarding the spatial and temporal heterogeneity of the tumor [46], limited accessibility to the tumor tissue which could increase the possibility of false negative results [46], and bleeding or infections as a consequence of an invasive biopsy or excisional procedure [47]. Vice versa, a liquid biopsy obtained with a routine blood draw overcomes many of these limitations [48]; liquid biopsy could be used as a rapid tool for the diagnosis and monitoring of tumor progression and, possibly, for prediction of treatment response, detection of recurrence, and traceability of tumor genome evolution over time $[42,43,49,50]$, which would be almost impossible with solid biopsy (Table 1). 
Table 1. Advantages and disadvantages of liquid biopsy.

\begin{tabular}{|c|c|c|}
\hline & Advantages & Disadvantages \\
\hline & $\begin{array}{l}\text { Needs a small volume of blood } \\
\text { (usually } 6-10 \mathrm{~mL} \text { ) }\end{array}$ & Techniques not yet standardized \\
\hline \multirow{5}{*}{ LIQUID BIOPSY } & Not invasive & $\begin{array}{c}\text { Clinical practice rules are not yet } \\
\text { established }\end{array}$ \\
\hline & Easily repeated & $\begin{array}{l}\text { It is not reliable for all types of } \\
\text { cancer (e.g., lung cancers), the } \\
\text { diagnosis and subtyping can be } \\
\text { established by only histology }\end{array}$ \\
\hline & $\begin{array}{c}\text { Useful to reveal spatial } \\
\text { and temporal tumor } \\
\text { heterogeneity }\end{array}$ & $\begin{array}{l}\text { May not be representative of the } \\
\text { whole cancer }\end{array}$ \\
\hline & $\begin{array}{l}\text { Real time monitoring for drug } \\
\text { response and resistance }\end{array}$ & \\
\hline & $\begin{array}{c}\text { Timely search for genotyping } \\
\text { mutations }\end{array}$ & \\
\hline
\end{tabular}

Although the potential of liquid biopsy is emerging as a diagnostic and prognostic tool, some issues need to be solved before liquid biopsy becomes part of the clinical practice [51]. One important limitation of liquid biopsy in oncology is the low specificity and sensitivity, since alterations are detected in body fluids, and not in the tumor itself [29].

\subsection{Liquid Biopsy Biomarkers vs. Classical Biomarkers in Cancer Cachexia}

Although liquid biopsy is commonly used and studied in cancer, it might be also applicable to several conditions, including cancer cachexia, to identify/diagnose it at an early stage. Liquid biopsy might be an alternative to muscle or adipose tissue biopsies to obtain information on the molecular changes occurring in these compartments over time and to monitor the process of skeletal muscle and adipose tissue atrophy in a less invasive way compared to surgical biopsies, especially in a research setting.

A prognostic indicator of the therapeutic response in cancer cachexia would be fundamental for the success of the treatment [21,22]. Considering that skeletal muscle represents the most affected organs in cancer cachexia and a main target for cachexia prevention and treatment, liquid biopsy biomarkers in cancer cachexia need to be, by definition, directly produced by skeletal muscle. Therefore, they would be much more specific with respect to classical cachexia biomarkers which are not necessarily produced by skeletal muscle.

It has been proposed that the mediators involved in the pathogenesis of CC, such as the pro-inflammatory cytokines IL- 6 and TNF- $\alpha$, hormones (e.g., leptin and ghrelin), and peptides, such as CAF [22,23], could be used as classical biomarkers in the development and progression of cachexia, although the exact role of these molecules has not been fully elucidated yet $[23,25]$. However, they are interesting because their concentration in the bloodstream of cachectic patients seems to be different compared to healthy subjects; e.g., ghrelin concentration decreases whereas pro-inflammatory cytokines, myostatin and growth and differentiation factor 15 (GDF-15) concentrations increase [52]. Due to the multifactorial nature of cachexia, a molecular mediator that fully satisfies the characteristics of an ideal biomarker:easily accessible, sensitive, reproducible and not expensivehas not yet been identified [21-23]. Among potential biomarkers of cancer cachexia, some are produced by skeletal muscle, which makes these molecules eligible as potential liquid biopsy biomarkers [23,51]. For example, CAF [53], collagen fragments, as well as the 3-methylhistidine derived from actin, myosin and titin fragments, released from atrophic muscles, might be considered as possible liquid biopsy biomarkers [54]. Similarly, myostatin (growth and differentiation factor 8; GDF-8), belonging to the transforming growth factor- $\beta$ (TGF- $\beta$ ) superfamily, seems to play a critical role in cachexia being a negative regulator of muscle growth [23]. Since it is mainly produced by skeletal muscle, it might be 
a potential liquid biopsy biomarker [55] similar to some pro-inflammatory cytokines and some miRNAs also produced by this tissue.

\section{3. miRNAs}

Recent data [56-58] indicated that miRNAs and the alteration of the complex network between them and their mRNA targets could be responsible for the onset/progression of cachexia or for the systemic inflammation associated with this condition, although to date these points remain to be fully elucidated $[6,7,24,40,51,59-73]$.

The miRNAs are included in the category of cfNAs, which were identified in human plasma for the first time in 1948 [29,59]. miRNAs are single-stranded, small non-coding RNAs with a size of $\sim 22$ nucleotides. They were discovered in 1993 and are present in all living organisms (viruses, algae, plants, invertebrates and vertebrates) [60-62].

In the present review we focused our attention on circulating, muscle-produced miRNAs detection through liquid biopsy as an alternative to invasive skeletal muscle solid biopsy. The reason for this is that miRNAs have many features in common with an ideal biomarker, among which they are stable in body fluids since they are resistant to RNAse digestion, to extreme $\mathrm{pH}$, as well as to high temperatures and to repeated freeze-thaw cycles $[32,41,74-76]$. In addition, they are easily accessible through the repeatable and less invasive liquid biopsy method compared to the anatomical and clinical difficulties that can be encountered in performing a surgical biopsy [29,51].

\subsection{Summary of the Biogenesis of miRNAs}

The biogenesis of miRNA begins within the nucleus where the RNA polymerase II synthesizes a primary transcript, called pri-miRNA which undergoes several maturation processes. Pri-miRNAs have a length of about 100 nucleotides and can be transcribed by their promoters, located in intragenic (mostly introns but also exons) and intergenic regions $[77,78]$. Pri-miRNAs are characterized by inverted and close repetitions that pair forming a hairpin structure (Figure 1).

Two mature miRNAs could originate from the pri-miRNA; one from the $5^{\prime}$ arm and one from the $3^{\prime}$ arm of the hairpin, therefore they take the suffix $-5^{\prime}$ or $-3^{\prime}$, respectively [79] (Figure 1). In some cases, a single, long primary transcript gives rise to more than one mature miRNA; they form a cluster and the miRNAs contained in it constitute a family. For example, miR-29a, miR-29b and miR-29c belong to the miR29 family [80-82].

Pri-miRNAs are cleaved by a microprocessor multiprotein complex consisting of Drosha, a nuclear RNAse III, and the double-stranded RNA binding protein Pasha/Di George syndrome chromosomal region 8 (DGCR8) [83], which allows the formation of a short double helix called pre-miRNA [79] which migrates from the nucleus to the cytoplasm via exportin-5 (Figure 1). Into the cytoplasm, the RNAse III Dicer removes the hairpin that joins the $3^{\prime}$ and $5^{\prime}$ arm, producing a mature miRNA/miRNA * duplex, consisting of a guide and of a passenger strand (here indicated with an asterisk). Some RNA-binding proteins, including the endoribonuclease Argonauta2 (AGO2), bind the miRNA duplex to form the RNA-Induced Silencing Complex (RISC), which unwinds the duplex of miRNA, leaving the guide strand bound to the AGO2 protein ready to perform its regulatory function, while the passenger strand is degraded [84] (Figure 1) The selection of which strand of the miRNA/miRNA * duplex will be the guide and which one the passenger strand, is thought to be determined by their thermodynamic stability and by their composition. Generally, the guide strand is the one with the lower thermodynamic stability at the $5^{\prime}$ end or the one containing an uracil at the $5^{\prime}$ end [85-87]. The guide strand is usually the more prevalent and more biologically active among the two [79].

As recently reported by O'Brien and colleagues [84], a "non-canonical" miRNA biogenesis pathway has also been identified. In this pathway, miRNA's processing is independent from Drosha/DGCR8 and/or Dicer. Nevertheless, the final result is the same; the protein AGO2 binds the mature miRNA to form the RISC complex [84]. 


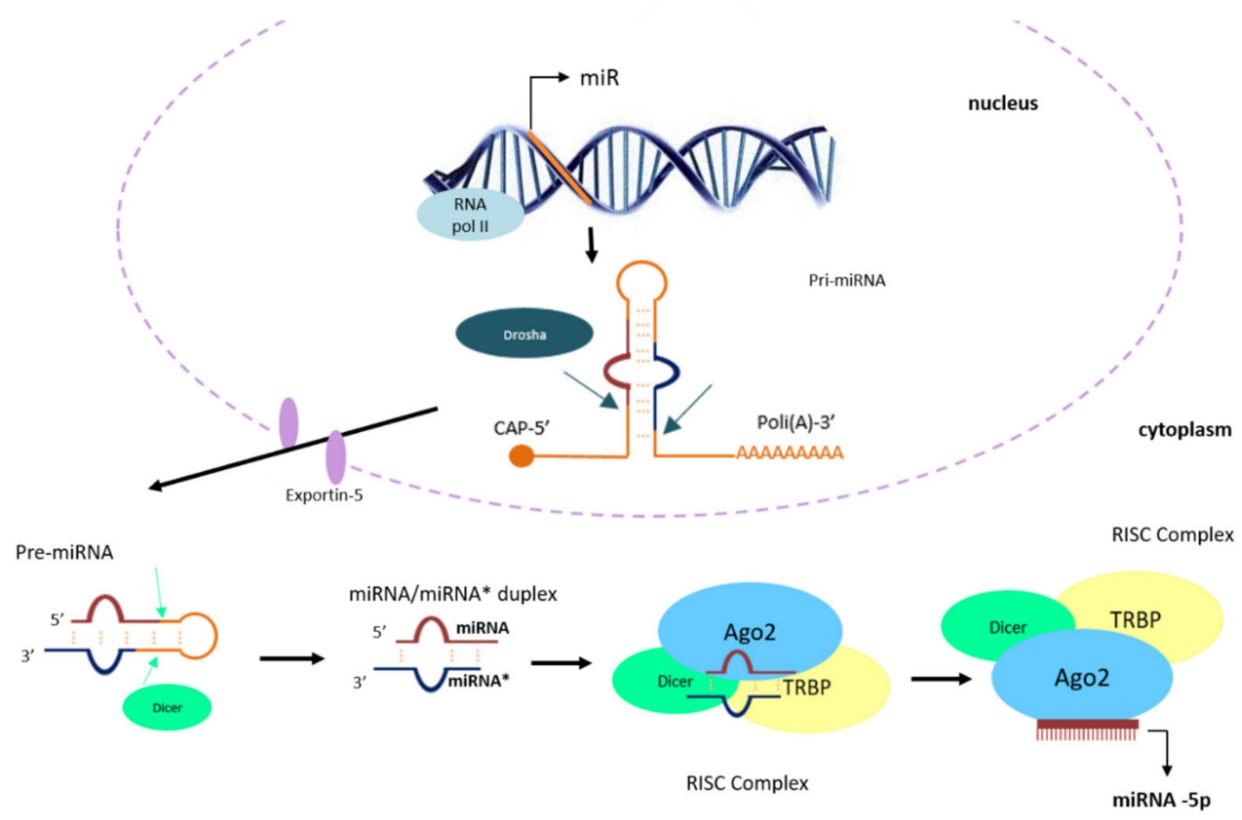

Figure 1. Biogenesis of microRNAs. Within the nucleus, RNA polymerase II synthesizes a long primary miRNA (primiRNA), from intronic, exonic or intragenic sequence. Pri-miRNA is characterized by a hairpin structure due to the pairing of inverted and close repetition. The microprocessor complex, consisting of Drosha (nuclear RNAse III) and Di George syndrome chromosomal region 8 (DGCR8), cleaves the pri-miRNA to form a precursor miRNA, a double helix called pre-miRNA. The pre-miRNA is exported to the cytoplasm in an Exportin-5/RanGTP-dependent manner. Dicer processes pre-miRNA into the cytoplasm by removing the terminal loop that forms the hairpin, giving rise to a miRNA/miRNA duplex * consisting of a guide and passenger strand (indicated with an asterisk). Both strands originated from this miRNA maturation process are loaded onto ARGONAUTA2 (AGO2) protein in an ATP-dependent manner, to form an effector complex called RNA-Induced Silencing Complex (RISC). The RISC Complex is formed by the miRNA/miRNA * duplex loaded to the AGO2 protein, but also by Dicer and the TAR RNA-binding protein (TRBP) protein, which contribute to the formation of the mature RISC complex. In the formation of the effective, mature RISC complex, AGO2 unwinds and cleaves the passenger strand, giving rise to a mature single-stranded miRNA, which will perform the regulatory function. Two mature miRNAs could be originated from the pri-miRNA; one from the $5^{\prime}$ arm and one from the $3^{\prime}$ arm of the hairpin thus they take the suffix $-5^{\prime}$ or $-3^{\prime}$ respectively.

In the RISC complex, the single stranded miRNA associates with its target mRNA having a complementary sequence. By this miRNA-mediated mechanism, the regulation of gene expression occurs at the post-transcriptional level, through the degradation or the inhibition of the target mRNA translation $[88,89]$. A miRNA can silence many mRNAs, and a single mRNA can be the target of multiple miRNAs. Generally, the miRNA binds the $3^{\prime}$ UTR region of the mRNA, however, although less frequently, miRNA interactions with the 5'UTR region and coding regions have also been reported [90]. The silencing mechanism induced by the miRNA depends on the degree of complementarity between the miRNA and target mRNA: a decreased complementarity determines the inhibition of the translation, whereas a perfect complementarity causes the degradation of the mRNA [91]. It has been shown that miRNAs are also capable of binding promoter regions, thus inducing gene transcription [92]; however, more studies are required to better understand the underlying mechanism.

\subsection{Circulating miRNAs and Their Biological Implications}

miRNAs were first identified in tissues and subsequently in liquid biopsies. The total concentration and the composition of miRNAs vary among the different biological fluids. Identification of extracellular miRNAs generated high interest in the scientific community because biological fluids contain RNAses, enzymes that perform a protective function against exogenous nucleic acids [37]. It has been proposed that miRNAs are very 
stable in biological fluids because they can escape from the RNAses activity, through two possible ways: being packaged in extracellular vesicles (EVs) or being associated with proteins [93] (Figure 2). In vitro studies have shown that muscle-derived miRNAs can be released into the bloodstream $[6,7,73]$, making these molecules potential indicators of muscle metabolism.

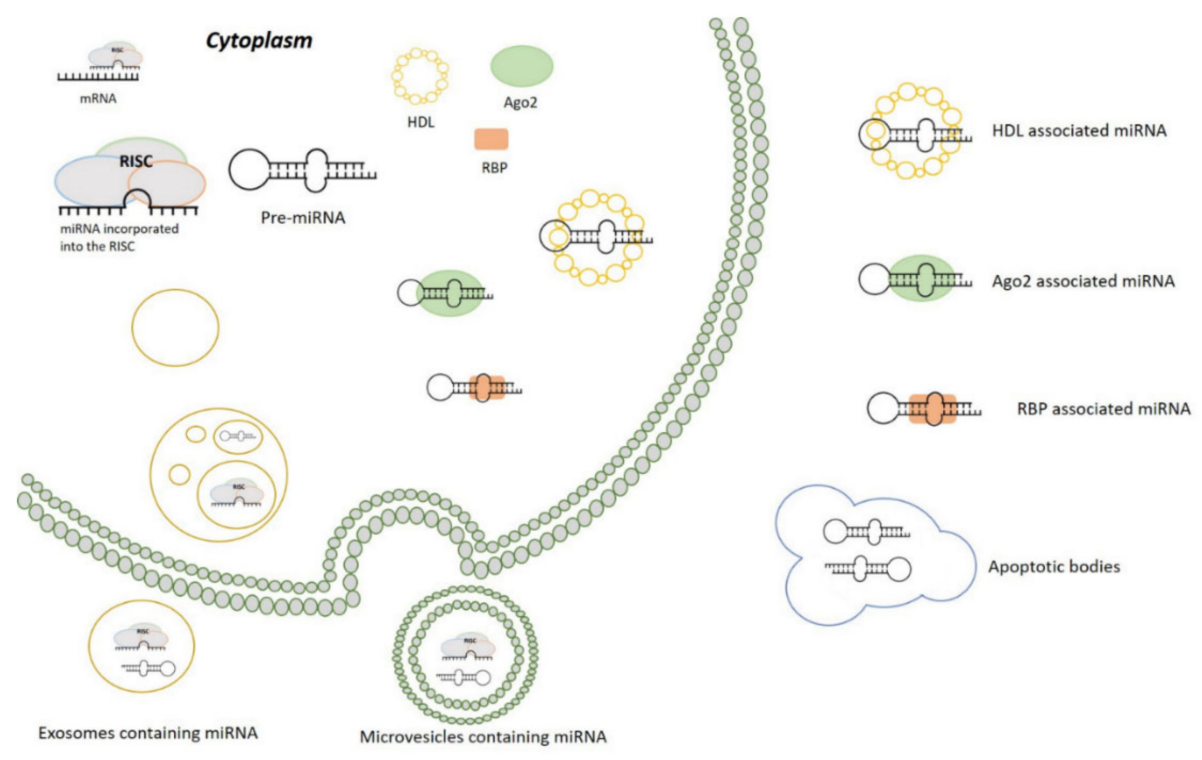

Figure 2. microRNA release mechanisms. miRNAs can be released into the extracellular space through several mechanisms: both pre-miRNAs and mature miRNAs, loaded into the RISC complex, can be incorporated into exosomes or microvesicles and secreted from the donor cell. Circulating miRNAs can also be derived from apoptotic bodies. Moreover, miRNA can be stable in biological fluids in association with RNA-binding proteins (RBP), Ago2 or HDL.

\subsection{1. miRNAs Packaged in EVs}

EVs are small particles surrounded by a plasma membrane and containing several cytosolic molecules (miRNA, mRNA, DNA, proteins and lipids) derived from the donor cells [31,94]. RNAses cannot enter these vesicles [40].

EVs constitute a heterogeneous population of particles of different sizes, biochemical composition, density, tissue of origin, function and biogenesis $[95,96]$. Recently, EVs have been classified into three classes named exosomes, ectosomes/microvesicles and apoptotic bodies, based on their size and mechanism of biogenesis [97].

Exosomes are nano-sized vesicles $(30-150 \mathrm{~nm})$ of endosomal origin, which are released in the extracellular environment by fusion between endocytic vesicles and plasma membrane through an active and finely regulated process. They originate by the fusion between an early endosome, also called multivesicular body (MVB), and plasma membrane $[40,97,98]$. All cell types are able to release exosomes, and the exosome cargo allows to identify the originating cell $[40,99]$.

Ectosomes (also called microvesicles) (100-1000 nm) originate from the outward budding of the plasma membrane [100]. Following an extracellular signal, the donor cell forms a protrusion of the plasma membrane whose detachment originates these vesicles [101,102].

Apoptotic bodies are vesicles larger than $800 \mathrm{~nm}$, produced by fragmentation of the apoptotic cell which releases these vesicles into the extracellular space [103,104]. Some of EVs are the oncosomes, vesicles containing miRNA, mRNA and proteins that are actively produced by cancer cells and released into biological fluids $[95,99,105,106]$. Once released into body fluids, miRNAs can act as messengers and regulate cell functions in an autocrine, paracrine or endocrine manner [9,95,102,107-109]. Interestingly, experimental studies showed that miRNAs contained in EVs can trigger muscle atrophy in vitro $[7,73]$. 


\subsection{2. miRNAs Associated with Protein}

The second way in which miRNAs are able to escape from the activity of RNAses is through their association with proteins. Arroyo and colleagues [33] were the first to demonstrate that miRNAs are released into biological fluids not only packaged in vesicles. They speculated that miRNAs are associated with elements that made them stable in the blood, protected against the RNAses activity [33]. Subsequently, they revealed the presence of $\mathrm{AGO} 2$ in body fluids, demonstrating that miRNAs can be associated with ribonucleoprotein complexes giving them stability. Other studies showed that miRNAs in body fluids can also be bound to the protein nucleophosmin, as well as to lipoproteins (HDL and LDL) [33,109-117].

Nowadays we still do not know the exact mechanisms of miRNA's export systems from cells. Two possible mechanisms have been hypothesized, a passive and an active one [111]. The passive mechanism allows the release of miRNAs as by-products of cells, both packaged in EVs or associated with proteins [97,118], for example following apoptosis or necrosis [32,74,103,119-121]. On the other hand, miRNAs can be released as EVs and EVs-free forms, by an active mechanism $[33,112,120,122,123]$. Noteworthy, in vitro studies showed that miRNAs can also be exchanged between cells through gap junction or through direct cell-to-cell contacts [117].

These mechanisms represent a strategy of cell-to-cell communication and gene expression regulation between cells located at a considerable distance in the organism $[120,121,124,125]$. In this light, analyzing the levels of muscle-derived miRNAs released in biological fluids (both EVs and EVs-free form), could allow us to obtain information on muscle metabolism during cancer cachexia.

\section{Skeletal Muscle-Derived miRNAs as Potential Candidate for Liquid Biopsy Biomarkers in Cancer Cachexia}

4.1. Murine and Human Circulating Muscle-Derived miRNAs as Liquid Biopsy Biomarkers for Cancer Cachexia

The loss of muscle mass during cachexia is determined by an imbalance between the rates of protein synthesis and degradation, in addition to several metabolic changes occurring systemically in the muscle $[25,70,71,126-130]$.

Many researchers have focused on the role of muscle-derived miRNAs in muscle growth and muscle atrophy pathways, as also reported by Donzelli et al. [131]. miRNAs expressed in skeletal muscle such as miR1, miR133a, miR133b, miR206 and miR486 were found to be involved in cancer cachexia. They directly modulate the processes of myogenesis, growth, differentiation and apoptosis of myotubes, as well as protein synthesis and skeletal muscle homeostasis [132-137]. Myo-miRNAs are specifically expressed in skeletal muscle since their genes are either located into the intronic regions of the Myosin Heavy Chain $(\mathrm{MyHC})$ genes or they are directly controlled by specific muscle transcription factors such as Myoblast Determination protein 1 (MyoD), Myocyte enhancer factor-2 (Mef2), or Serum responsive factor (Srf) [138-142].

As will be specifically described below, the circulating levels of these muscle-expressed miRNAs are modulated during cancer cachexia [2-7,71,143]. For this reason, they are gaining increasing interest in liquid biopsy in cancer cachexia [144-147]. (Figure 3). 


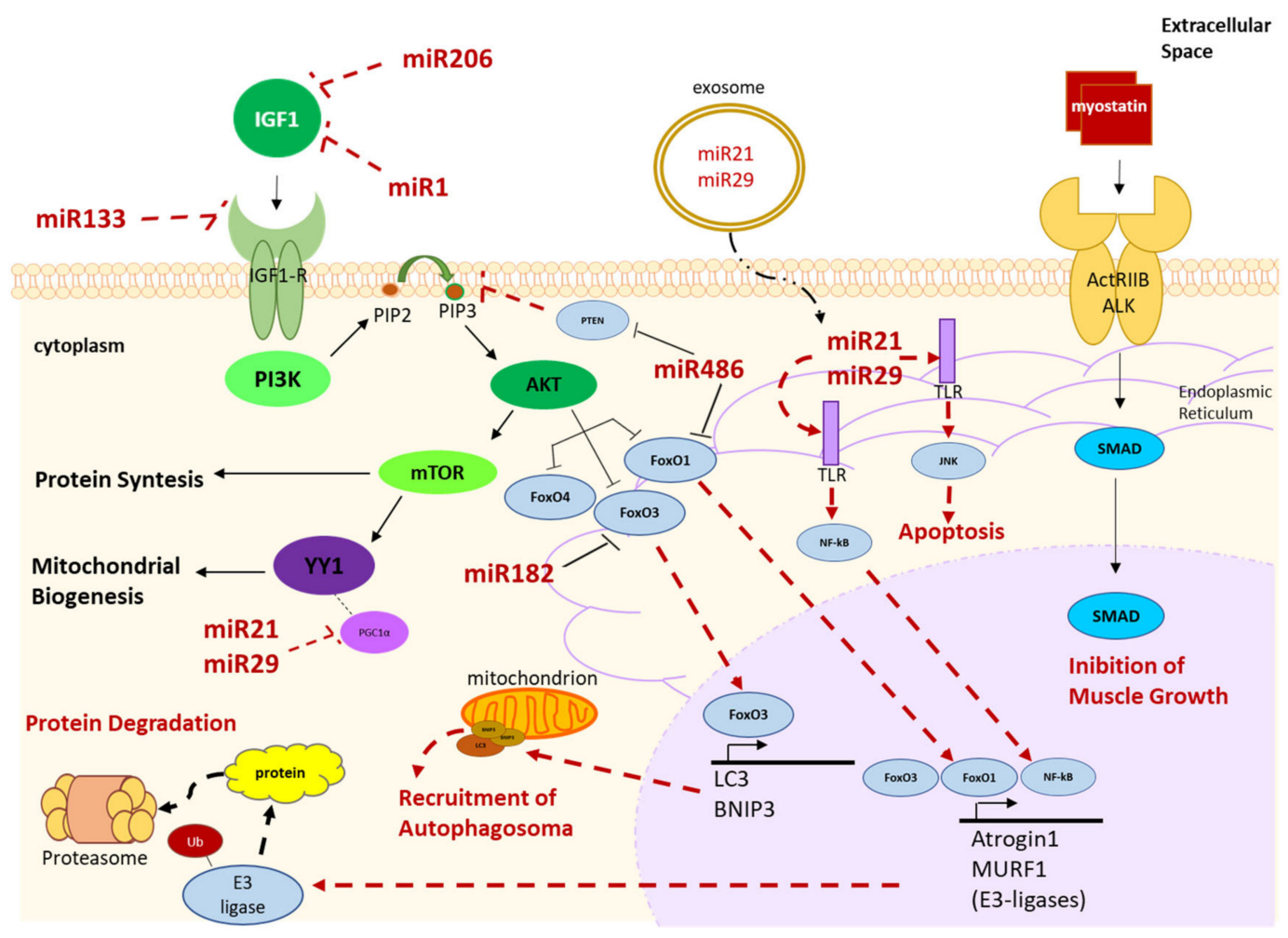

Figure 3. Schematic representation of miRNAs involved in the regulation of atrophy and protein degradation pathways in skeletal muscle tissue. Insulin-like growth factor 1 (IGF-1) activates the Akt/mTOR signaling pathway, responsible for protein synthesis. Akt inhibits the degradation of proteins by keeping inactive in the cytoplasm transcription factors members of the forkhead box protein $\mathrm{O}$ (FoxO) family (FoxO1, FoxO3 and FoxO4), which otherwise migrate in the nucleus and promote the transcription of the E3 ligases (Atrogin1 and MuRF1), responsible for the protein degradation mediated by the system of the ubiquitin proteasome. In the nucleus FoxO3 is also able to promote the transcription of microtubuleassociated protein 1A/1B-light chain 3 (LC3) and BCL2 Interacting Protein 3 (BNIP3) which once in the cytoplasm localize on the outer membrane of the mitochondria, promoting mitophagy through the recruitment of the autophagosome. The $\mathrm{Akt} / \mathrm{mTOR}$ pathway is also able to promote the activation of the factor Yin Yang 1 (YY1) which, associating with peroxisome proliferator activated receptor gamma coactivator 1 alpha $(\mathrm{PGC} 1 \alpha)$, induces mitochondrial biogenesis. Akt activation is inhibited by phosphatase and tensin homolog (PTEN) which inhibits the phosphorylation of PIP2 to PIP3. Several in vitro and in vivo studies have shown that elevated circulating levels of miR-1, miR-133a/b and miR-206 appear to negatively regulate the IGF-1/Akt/mTOR pathway, by targeting positive regulators IGF-1 and IGF1-receptor (IGF-1R) thus promoting muscle wasting. On the contrary, miR-486 and miR-182 promote protein synthesis, by targeting negative regulators of this signaling pathway (PTEN, FoxO1-3). miR-21 and miR-29 contained in the exosomes can penetrate the muscle fiber and activating the TLR7/8 located on the endoplasmic reticulum promoting i) the activation of JNK which induces apoptosis of the muscle fiber and ii) NF-kB which, migrating in the nucleus, promotes the transcription of Atrogin1 and MuRF1, responsible for protein degradation. miR21 and miR29 in skeletal muscle tissue are also able to negatively regulate mitochondrial biogenesis by targeting YY1. Finally, the signaling pathway induced by myostatin activates SMADs (2-3-4) which, by moving to the nucleus, inhibit muscle growth. Dashed arrows indicate the pathways that lead to muscle wasting. Dashed lines indicate the inhibitory function of miRNAs in skeletal muscle tissue. Black arrows indicate the pathways involved in muscle homeostasis.

Murine and Human Circulating Muscular miRNAs Involved in the Insulin-Like Growth Factor 1 (IGF1)/Akt/mTOR Pathway

$m i R 1, m i R 133 a / b$ and $m i R 206$ are skeletal muscle-expressed miRNAs since they are all expressed in skeletal muscles [148,149]. miR1 and miR133a are also produced by the cardiac muscle [150,151]. In vitro experiments on both human and mouse muscle cells showed that high levels of miR1 and miR133a/b are released by myotubes in extracellular space $[6,7,148,149]$. Interestingly, as discussed below, the levels of these miRNA are modulated in mouse models of muscle wasting conditions both in the skeletal muscle tissue, thus 
suggesting an autocrine/paracrine function, and in the blood thus suggesting an endocrine role for them $[6,7,71,72,143]$.

The miR1-1/miR133a-2, miR1-2/miR133a-1 and miR133b/miR206 [132] are clustered in different genes/chromosomes. However, although two miRNAs are in the same cluster, their transcription can take place separately [152]. miR1 is mainly expressed in the fast-twitch glycolytic fibers while miR206 is expressed in the slow-twitch oxidative fibers [153,154]. Both miRNAs have the same molecular target, IGF1 (Figure 3). Therefore, high circulating levels of miR1 and miR206 block the IGF1/Akt/mTOR pathway, which is the main pathway regulating myofiber size by activating protein synthesis and mitochondrial biogenesis $[155,156]$ (Figure 3). Blocking the IGF1/Akt/mTOR pathway results in increased protein degradation and muscle atrophy $[148,149,157]$. The same signaling pathway is inhibited by high circulating levels of $\mathrm{miR133a} / \mathrm{b}$ since its molecular target is the IGF1 receptor (IGF1-R) [148,149] (Figure 3).

Accordingly, Cacchiarelli and colleagues observed elevated levels of miR1, miR133 and miR206 in the blood of patients with Duchenne muscular dystrophy, whereas the expression levels of these miRNAs in skeletal muscle tissue of the same patients were low [158]. Moreover, Köberle [159] hypothesizes that the progression of cachexia could lead to a reduction in circulating myo-miRNAs (especially miR1), due to advanced muscle wasting [147]. Interestingly, miR1 and miR206 have also been suggested to be involved in myogenic differentiation. In fact, MyoD and Myogenin seem to promote the overexpression of miR1 and miR206 and high levels of these miRNAs have been found to decrease the expression of Pax7 compared to MyoD, thus resulting in increased satellite cell differentiation $[127,129,140,160-162]$.

The miR486 is defined "muscle-enriched" because its expression level is higher- but not exclusive- in skeletal muscle relative to other tissues [163]. It has autocrine/paracrine effects; in fact, in physiological conditions, miR486, in myofibers, keeps forkhead box protein $\mathrm{O} 1$ (FoxO1) inactive, thus dampening autophagy and muscle atrophy [164] (Figure 3). Another molecular target of miR486 is represented by phosphatase and tensin homolog (PTEN) which acts by inhibiting the phosphorylation of PIP2 to PIP3, thus blocking the activation of the AKT/mTOR pathway (Figure 3). Under normal physiological conditions miR486 decreases the expression of PTEN, thus allowing protein synthesis [165]. Therefore, the down-regulation of this miRNA at tissue level leads to a decrease in protein synthesis and to an increased expression of Atrogin1 and MuRF1 mediated by FoxO1, which leads to myofiber atrophy [148,165] (Figure 3). The expression of miR486 seems to be regulated by $\mathrm{MyoD}$ and its over-expression would appear to promote the differentiation of myoblasts $[145,146]$. Xu and colleagues $(2012)$ demonstrated that high expression of miR486 in skeletal muscle tissue improve muscle mass of mice models of chronic kidney disease $[6,164]$. This muscle-enriched miRNA has also been found to be circulating, both in humans and mice $[6,164,166,167]$.

\subsection{Other Human Skeletal miRNAs as Potential Future Liquid Biopsy Biomarkers for Cancer Cachexia}

Other skeletal muscle-derived miRNAs have been more recently found to be modulated in cancer cachexia, also having in most cases an important prognostic value $[131,168,169]$.

However, in order to be used as liquid biopsy biomarkers, it will be necessary to assess their presence also in body fluids during cachexia. It will also be important to evaluate if their circulating moieties are modulated during cancer cachexia, like their skeletal muscle counterpart do and also if they derive from skeletal muscle; this issue might be investigated analyzing the miRNAs contained into EVs, since the origin of EVs might be confirmed by analyzing their surface markers [97]. Once established that a specific modulated circulating miRNA is released by the skeletal muscle, this could be used as liquid biopsy biomarker and directly amplified on the total RNA extracted by the liquid biopsy. On the other hand, if a specific miRNA is released by several different tissues, then EVs isolation and identification, followed by miRNA quantification should be performed. However, it has to be taken into account that exosomes were observed to contain a small minority of the miRNA content in plasma. Therefore, it has been suggested that exosomes are individually unlikely to 
be vehicles for miRNA-based intercellular communication [170]. In this perspective, we acknowledge that this is a complex procedure difficult to be implemented routinely as a prognostic tool.

In 2017, a study conducted on human rectus abdominus biopsies identified eight tissue-related miRNAs (let-7d-3p, miR199a-3p, miR345-5p, miR423-5p, miR423-3p, miR532$5 p$, miR1296-5p and miR3184-3p) upregulated in cachectic cancer patients compared to non-cachectic cancer patients [144]. If this difference was also found in the bloodstream, these miRNAs might be considered potential biomarkers of muscle wasting during cancer cachexia.

More recently, other skeletal muscle miRNAs (miR18a, miR208a, miR208b, miR422a, $m i R 499$, miR542-5p and miR542-3p) have been proposed to play a role in the pathophysiology of cancer cachexia $[131,168]$. In particular, both in vitro and in vivo studies (human samples but also mouse models) showed overexpression of miR18a, miR422a; miR542-5p/3p in skeletal muscle tissue during muscle wasting conditions [168]. However, in silico analysis [131] and other in vivo experiments on mice [171] showed that decreased expression levels of miR208a and miR499 in skeletal muscles were related to decreased muscle mass [131,171]. Furthermore, van de Worp et al. [169] found additional miRNAs modulated in vastus lateralis muscle of lung cancer patients with cachexia (miR-424/miR-503 cluster and the miR144-3p/451a cluster). The first miRNA cluster includes miR424-5p, miR424-3p, miR450a-1, miR450a-2, miR450b, miR503, miR542-5p, miR542-3p [169]. They reported an overexpression of miR424-3p, miR424-5p and miR450a, whereas miR144-5p and miR451a were downregulated in cachectic cancer patients [169]. Based on the results obtained both in silico analysis and in experimental models (in vitro and in vivo, humans), the downregulation of miRNAs miR27a/b and miR182 seems to be associated with cancer cachexia $[81,143,149,168]$.

\subsubsection{Human Muscle-Derived miRNAs Involved in the IGF1/Akt/mTOR Pathway}

miR18a, miR199a and miR345-5p regulate the IGF1/Akt/mTOR pathway and induce the expression of MuRF1 and Atrogin1, thus leading to a reduction in protein synthesis and to muscle atrophy $[64,144,168,172-177]$. They have therefore an autocrine/paracrine role. Besides the IGF1/Akt/mTOR pathway, another molecular target of miR345-5p is the extracellular matrix (ECM) protein, alpha-1 type I collagen (COL1A1), whose downregulation in skeletal muscles of cachectic patients, is associated with muscle atrophy [144]. Furthermore, another target of miR345-5p is the Transferrin Receptor (TFRC), which was down-regulated in the muscle of these patients [144]. Transferrin influences skeletal muscle homeostasis, and it has been speculated that its down-regulation might lead to an imbalanced myogenic differentiation [144,178]. Similarly, miR486, miR182 has FoxO3 as its molecular target and regulates the process of autophagy and atrophy in skeletal muscle [143].

\subsubsection{Human Muscle-Derived miRNAs Involved in Myogenic Differentiation}

The Let-7d-3p belongs to a miRNA family called Let-7. Similarly, to miR345-5p, Let-7d$3 p$ targets TFRC, that might affect myogenic differentiation which leads to skeletal muscle wasting [144]. The miR1296 is involved in the serotonin-mediated signaling pathway regulating myogenic differentiation [179]. Moreover, miR1296-mediated modulation of serotonin seems to be linked to food intake reduction [180].Also, miR3184-3p influences myogenic differentiation by regulating the WNT/ $\beta$-catenin signaling pathway [144].

\subsubsection{Human Muscle-Derived miRNAs Involved in the Myostatin/Smad Pathway}

Based on in silico predictions, the target of $m i R 208 a / b$, miR422a miR499 and miR542$5 p / 3 p$ might belong to the Myostatin/Smad pathway, a major pathway negatively regulating muscle growth $[131,149,168,181]$. miR27 $a / b$ also seems to be involved in the Myostatin signaling pathways although there are few experimental data confirming this function $[148,149,168]$. 


\subsubsection{Human Muscle-Derived miRNAs Involved in Skeletal Muscle Homeostasis}

The $m i R 423-5 p$ and miR532-5p are regulators of the energy metabolism [144]. In fact, miR423-5p modulates the intramuscular levels of leptin, while a molecular target of miR532-5p is the Neuro Peptide Y Receptor (NPYR), whose down-regulation could contribute to the pathophysiology of cancer cachexia [144]. miRNA424-5p seems to have as molecular targets proteins involved in the rRNA synthesis, thus modulating the translation machinery [168]. However, although modulations of miRNAs belonging to these clusters are reported in different types of cancer, their function is not yet fully understood.

The results reported in these studies indicate an autocrine/paracrine function for all the human miRNAs described in this section; experimental studies confirming the presence of circulating levels of such miRNAs are needed to propose an endocrine function for them and their potential utility as liquid biopsy biomarkers for cancer cachexia.

\subsection{Other Skeletal miRNAs Identified in Mouse Models of Cancer Cachexia}

Finally, data indicate the involvement of other miRNAs modulated in skeletal muscle of cancer cachexia mice models such as miR223-3p, miR229a-3p miR299a-3p, miR431-5p, miR511-3p, miR665-3p, miR1933-3p and miR3473d, as well as miR147-3p and miR205-5p [71,182]. Specifically, Lee et al. found the upregulation of miR147-3p, miR511-3p, miR223-3p and miR205-5p in the tibialis anterior of cancer cachexia mouse models, whereas other six miRNAs were downregulated in these muscle samples [71]. This suggests an autocrine/paracrine function for these miRNAs in this setting.

Most of these skeletal muscle-derived miRNAs have also been detected in the bloodstream [40,183-199]. However, to date it is unknown whether their circulating levels are modulated during cancer cachexia in humans. Further studies are necessary to clarify this point which appears crucial in order to evaluate the potential role of these miRNAs in liquid biopsy for cancer cachexia.

\section{From Research to Clinical Practice: Steps to Be Improved in Order to Use Circulating Skeletal Muscle Derived-miRNAs in Liquid Biopsy}

In physiological conditions, muscular and circulating muscular miRNAs maintain skeletal muscle homeostasis and are expressed at low concentrations in biological fluids [163], while their up- or down-regulation has been observed in several diseases [41,200-203]. While promising results have been achieved by using experimental cachexia models, results on miRNAs obtained in humans are controversial and need more effort to become definitive due mainly to the higher variability of cachectic patients. Robust data are necessary to standardize a protocol to allow the greatest recovery of miRNA and minimizing hemolysis in serum or plasma to use liquid biopsies as a source of circulating skeletal muscle derived-miRNAs [204-206]. To date, the choice of serum or plasma as the better source for circulating miRNA extraction is still debated. According to Vigneron and colleagues, the presence of EDTA in the plasma tube could inhibit the precipitation of RNA and reduce hemolysis [207]. To note, miRNA16-5p is very often used as an endogenous control and differences in the concentration of this miRNA in serum and plasma make non-univocal the interpretation of the results [207].

Noteworthy, in addition to the variability associated to the different types of biological fluids used as liquid biopsy, there is also a variability between the methods and kits used to perform the analysis [31,207-209] that may influence the yield and quality of the extracted RNA [149], thus indicating discrepancies related to the method used rather than a real difference [207-209]. To date, quantitative Real-Time PCR is the "gold standard" for miRNA analysis [147], however, there are several kits (also very different from each other) available to perform retro-transcription (RT) and Real-Time PCR steps. Standardized methods for collecting biological fluids, for RNA extraction and for the RNA quantification would make possible the comparison of data obtained by different researchers $[41,51,207,210]$.

Importantly, in order to use circulating miRNAs in liquid biopsy, it is necessary to identify a reliable endogenous control that is constitutively and stably expressed in all subjects and that is not modulated during pathological conditions [146]. Some research groups have recently 
used a combination of two or more miRNAs as endogenous controls [211-213]. Moreover, several circulating miRNA extraction kits provide the use of an exogenous control [211,214], a non-human miRNA, with a known concentration, to be added in the miRNA extraction phase. Comparing the data relative to the exogenous control with those relative to the endogenous control, it would be possible to verify the efficacy of both the chosen endogenous control and the execution of the method $[130,201,211,214,215]$. Also, it appears necessary to identify the reference values for circulating miRNAs in healthy subjects in order to clarify the variability related to different factors including sex, ethnicity, age, diet, physical activity and all the factors influencing the expression of circulating miRNAs [146,147].

\section{Conclusions}

The diagnosis of cancer cachexia occurs generally late if compared to the onset of the profound metabolic alterations leading to loss of muscle mass and to reduced food intake typical of this syndrome. For this reason, it is crucial to identify reliable biomarkers to be detected in a non-invasive manner and allowing an early diagnosis of cachexia. In this light, it could be possible to develop targeted interventions to improve the outcomes. The discovery of circulating miRNAs and the use of liquid biopsy has opened a new, interesting scenario in the field of cancer research. Circulating miRNAs could play a key role as biomarkers in revealing the onset and progression of cachexia, which is characterized by systemic metabolic and nutritional alterations. Several studies on animal models showed an involvement of muscular miRNAs in the pathophysiology of cancer cachexia. However, there are discrepancies among the studies on the role of miRNAs in human cachexia. These limits are due both to the high variability of cachectic cancer patients and to the lack of standardized protocols for miRNA's analysis. Furthermore, the mechanisms identified in experimental animal models might not always exactly reflect the molecular interactions occurring in humans.

For this reason, increasing the knowledge about the miRNA pathways and tissue/organs cross-talk, may allow the application of miRNAs as diagnostic and prognostic biomarkers in the setting of cancer cachexia.

Author Contributions: R.B. and E.F. equally contributed to the study, writing the original draft preparation. R.B., R.C. and F.T. creation of the figures and the table. E.F., A.M., R.B., P.C. and M.M.; writing-review and editing. E.F., A.M. and M.M.; funding acquisition; M.M. supervision. All authors have read and agreed to the published version of the manuscript.

Funding: This work was supported by the Ph.D. Program of Innovative Biomedical Technologies in Clinical Medicine (to R.B.) at the Sapienza University of Rome and by “Parent Project aps Italy-2018 to E.F.

Institutional Review Board Statement: Not applicable.

Informed Consent Statement: Not applicable.

Data Availability Statement: No new data were created in this study.

Acknowledgments: We wish to thank M. L. Galluzzo for the valuable editorial work.

Conflicts of Interest: The authors declare that they have no conflicts of interest.

\section{References}

1. Muscaritoli, M.; Anker, S.; Argiles, J.M.; Aversa, Z.; Bauer, J.; Biolo, G.; Boirie, Y.; Bosaeus, I.; Cederholm, T.; Costelli, P.; et al. Consensus definition of sarcopenia, cachexia and pre-cachexia: Joint document elaborated by Special Interest Groups (SIG) "cachexia-anorexia in chronic wasting diseases" and "nutrition in geriatrics". Clin. Nutr. 2010, 29, 154-159. [CrossRef]

2. Barendregt, K.; Soeters, P.B.; Allison, S.P.; Sobotka, L. Simple and stress starvation. In Clinical Nutrition; Sobotka, L., Ed.; Galen: Somerville, MA, USA, 2004; pp. 107-113.

3. Molfino, A.; Amabile, M.I.; Muscaritoli, M. Nutrition support for treating cancer-associated weight loss: An update. Curr. Opin. Support. Palliat. Care 2018, 12, 434-438. [CrossRef] [PubMed]

4. Baracos, V.E.; Martin, L.; Korc, M.; Guttridge, D.C.; Fearon, K.C.H. Cancer-associated cachexia. Nat. Rev. Dis. Prim. 2018, 4, 17105. [CrossRef] [PubMed] 
5. Aversa, Z.; Costelli, P.; Muscaritoli, M. Cancer-induced muscle wasting: Latest findings in prevention and treatment. Ther. Adv. Med. Oncol. 2017, 9, 369-382. [CrossRef]

6. Camargo, R.G.; Quintas Teixeira Ribeiro, H.; Geraldo, M.V.; Matos-Neto, E.; Neves, R.X.; Carnevali, L.C., Jr.; Donatto, F.F.; Alcântara, P.S.; Ottoch, J.P.; Seelaender, M. Cancer Cachexia and MicroRNAs. Mediat. Inflamm. 2015, 2015, 367561. [CrossRef]

7. Calore, F.; Londhe, P.; Fadda, P.; Nigita, G.; Casadei, L.; Marceca, G.P.; Fassan, M.; Lovat, F.; Gasparini, P.; Rizzotto, L.; et al. The TLR7/8/9 Antagonist IMO-8503 Inhibits Cancer-Induced Cachexia. Cancer Res. 2018, 78, 6680-6690. [CrossRef] [PubMed]

8. Arends, J.; Bachmann, P.; Baracos, V.; Barthelemy, N.; Bertz, H.; Bozzetti, F.; Fearon, K.; Hütterer, E.; Isenring, E.; Kaasa, S.; et al. ESPEN guidelines on nutrition in cancer patients. Clin. Nutr. 2017, 36, 11-48. [CrossRef]

9. Ryan, A.M.; Power, D.G.; Daly, L.; Cushen, S.J.; Bhuachalla, E.N.; Prado, C.M. Cancer-associated malnutrition, cachexia and sar-copenia: The skeleton in the hospital closet 40 years later. Proc. Nutr. Soc. 2016, 75, 1-13. [CrossRef] [PubMed]

10. Roeland, E.J.; Bohlke, K.; Baracos, V.E.; Bruera, E.; Del Fabbro, E.; Dixon, S.; Fallon, M.; Herrstedt, J.; Lau, H.; Platek, M.; et al. Management of Cancer Cachexia: ASCO Guideline. J. Clin. Oncol. 2020, 38, 2438-2453. [CrossRef]

11. Bistrian, B. Systemic Response to Inflammation. Nutr. Rev. 2007, 65, S170-S172. [CrossRef]

12. Evans, W.J.; Morley, J.E.; Argilés, J.; Bales, C.; Baracos, V.; Guttridge, D.; Jatoi, A.; Kalantar-Zadeh, K.; Lochs, H.; Mantovani, G.; et al. Cachexia: A new definition. Clin. Nutr. 2008, 27, 793-799. [CrossRef]

13. Prado, C.M.; Sawyer, M.B.; Ghosh, S.; Lieffers, J.R.; Esfandiari, N.; Antoun, S.; Baracos, V.E. Central tenet of cancer cachexia therapy: Do patients with advanced cancer have exploitable anabolic potential? Am. J. Clin. Nutr. 2013, 98, 1012-1019. [CrossRef] [PubMed]

14. Cederholm, T.; Barazzoni, R.; Austin, P.; Ballmer, P.; Biolo, G.; Bischoff, S.C.; Compher, C.; Correia, I.; Higashiguchi, T.; Holst, M.; et al. ESPEN guidelines on definitions and terminology of clinical nutrition. Clin. Nutr. 2017, 36, 49-64. [CrossRef]

15. Costelli, P.; Baccino, F.M. Mechanisms of skeletal muscle depletion in wasting syndromes: Role of ATP-ubiquitin-dependent proteolysis. Curr. Opin. Clin. Nutr. Metab. Care 2003, 6, 407-412. [CrossRef] [PubMed]

16. Masi, T.; Patel, B.M. Altered glucose metabolism and insulin resistance in cancer-induced cachexia: A sweet poison. Pharmacol. Rep. 2021, 73, 17-30. [CrossRef] [PubMed]

17. Fearon, K.; Strasser, F.; Anker, S.D.; Bosaeus, I.; Bruera, E.; Fainsinger, R.L.; Jatoi, A.; Loprinzi, C.; MacDonald, N.; Mantovani, G.; et al. Definition and classification of cancer cachexia: An international consensus. Lancet Oncol. 2011, 12, 489-495. [CrossRef]

18. Argiles, J.M.; Muscaritoli, M. Unifying diagnostic criteria for cachexia: An urgent need. Clin. Nutr. 2017, 36, 910-911. [CrossRef] [PubMed]

19. Muscaritoli, M.; Fanelli, F.R.; Molfino, A. Perspectives of health care professionals on cancer cachexia: Results from three global surveys. Ann. Oncol. 2016, 27, 2230-2236. [CrossRef] [PubMed]

20. Gallagher, I.; Jacobi, C.; Tardif, N.; Rooyackers, O.; Fearon, K. Omics/systems biology and cancer cachexia. Semin. Cell Dev. Biol. 2016, 54, 92-103. [CrossRef]

21. Martins, T.; Vitorino, R.; Amado, F.; Duarte, J.A.; Ferreira, R. Biomarkers for cardiac cachexia: Reality or utopia. Clin. Chim. Acta 2014, 436, 323-328. [CrossRef]

22. Loumaye, A.; Thissen, J.-P. Biomarkers of cancer cachexia. Clin. Biochem. 2017, 50, 1281-1288. [CrossRef]

23. Molinari, F.; Malara, N.; Mollace, V.; Rosano, G.; Ferraro, E. Animal models of cardiac cachexia. Int. J. Cardiol. 2016, 219, 105-110. [CrossRef]

24. Carthew, R.W.; Sontheimer, E.J. Origins and Mechanisms of miRNAs and siRNAs. Cell 2009, 136, 642-655. [CrossRef] [PubMed]

25. Marinho, R.; Alcântara, P.S.M.; Ottoch, J.P.; Seelaender, M. Role of Exosomal MicroRNAs and myomiRs in the Development of Cancer Cachexia-Associated Muscle Wasting. Front. Nutr. 2018, 4, 69. [CrossRef] [PubMed]

26. Domínguez-Vigil, I.G.; Moreno-Martínez, A.K.; Wang, J.Y.; Roehrl, M.H.A.; Barrera-Saldaña, H.A. The dawn of the liquid biopsy in the fight against cancer. Oncotarget 2017, 9, 2912-2922. [CrossRef] [PubMed]

27. National Cancer Institute. Definition of Liquid Biopsy—NCI Dictionary of Cancer Terms; National Cancer Institute: Washington, DC, USA, 2018.

28. Alix-Panabières, C.; Pantel, K. Circulating Tumor Cells: Liquid Biopsy of Cancer. Clin. Chem. 2013, 59, 110-118. [CrossRef]

29. Qi, Z.H.; Xu, H.X.; Zhang, S.R.; Xu, J.Z.; Li, S.; Gao, H.L.; Jin, W.; Wang, W.Q.; Wu, C.T.; Ni, Q.X.; et al. The Significance of Liquid Biopsy in Pancreatic Cancer. J. Cancer 2018, 9, 3417-3426. [CrossRef] [PubMed]

30. Palmirotta, R.; Lovero, D.; Cafforio, P.; Felici, C.; Mannavola, F.; Pellè, E.; Quaresmini, D.; Tucci, M.; Silvestris, F. Liquid biopsy of cancer: A multimodal diagnostic tool in clinical oncology. Ther. Adv. Med. Oncol. 2018, 10, 1758835918794630. [CrossRef]

31. Ravegnini, G.; Sammarini, G.; Serrano, C.; Nannini, M.; Pantaleo, M.A.; Hrelia, P.; Angelini, S. Clinical relevance of circulating molecules in cancer: Focus on gastrointestinal stromal tumors. Ther. Adv. Med. Oncol. 2019, 11. [CrossRef]

32. Chen, X.; Ba, Y.; Ma, L.; Cai, X.; Yin, Y.; Wang, K.; Guo, J.; Zhang, Y.; Chen, J.; Guo, X.; et al. Characterization of microRNAs in serum: A novel class of biomarkers for diagnosis of cancer and other diseases. Cell Res. 2008, 18, 997-1006. [CrossRef]

33. Arroyo, J.D.; Chevillet, J.R.; Kroh, E.M.; Ruf, I.K.; Pritchard, C.C.; Gibson, D.F.; Mitchell, P.S.; Bennett, C.F.; Pogosova-Agadjanyan, E.L.; Stirewalt, D.L.; et al. Argonaute2 complexes carry a population of circulating microRNAs independent of vesicles in human plasma. Proc. Natl. Acad. Sci. USA 2011, 108, 5003-5008. [CrossRef] [PubMed]

34. Cogswell, J.P.; Ward, J.; Taylor, I.A.; Waters, M.; Shi, Y.; Cannon, B.; Kelnar, K.; Kemppainen, J.; Brown, D.; Chen, C.; et al Identification of miRNA Changes in Alzheimer's Disease Brain and CSF Yields Putative Biomarkers and Insights into Disease Pathways. J. Alzheimer's Dis. 2008, 14, 27-41. [CrossRef] [PubMed] 
35. Gallo, A.; Tandon, M.; Alevizos, I.; Illei, G.G. The majority of microRNAs detectable in serum and saliva is concentrated in exo-somes. PLoS ONE 2012, 7, e30679. [CrossRef]

36. Zhou, Q.; Li, M.; Wang, X.; Li, Q.; Wang, T.; Zhou, X.; Wang, X.; Gao, X.; Li, X. Immune-related MicroRNAs are Abundant in Breast Milk Exosomes. Int. J. Biol. Sci. 2012, 8, 118-123. [CrossRef] [PubMed]

37. Weber, J.A.; Baxter, D.H.; Zhang, S.; Huang, D.Y.; Huang, K.-H.; Lee, M.-J.; Galas, D.J.; Wang, K. The MicroRNA Spectrum in 12 Body Fluids. Clin. Chem. 2010, 56, 1733-1741. [CrossRef] [PubMed]

38. da Silveira, J.C.; Veeramachaneni, D.N.; Winger, Q.A.; Carnevale, E.M.; Bouma, G.J. Cell-secreted vesicles in equine ovarian fol-licular fluid contain miRNAs and proteins: A possible new form of cell communication within the ovarian follicle. Biol. Reprod. 2012, 86, 71. [CrossRef]

39. Ilié, M.; Hofman, P. Pros: Can tissue biopsy be replaced by liquid biopsy? Transl. Lung Cancer Res. 2016, 5, 420-423. [CrossRef] [PubMed]

40. Izzotti, A.; Carozzo, S.; Pulliero, A.; Zhabayeva, D.; Ravetti, J.L.; Bersimbaev, R. Extracellular MicroRNA in liquid biopsy: Ap-plicability in cancer diagnosis and prevention. Am. J. Cancer Res. 2016, 6, 1461-1493.

41. Harangus, A.; Berindan-Neagoe, I.; Todea, D.A.; Șimon, I.; Șimon, M. Noncoding RNAs and Liquid Biopsy in Lung Cancer: A Literature Review. Diagnostics 2019, 9, 216. [CrossRef]

42. Malara, N.; Trunzo, V.; Foresta, U.; Amodio, N.; De Vitis, S.; Roveda, L.; Fava, M.; Coluccio, M.L.; Macrì, R.; Di Vito, A.; et al. Exvivo characterization of circulating colon cancer cells distinguished in stem and differentiated subset provides useful biomarker for personalized metastatic risk assessment. J. Transl. Med. 2016, 14, 133. [CrossRef]

43. Malara, N.; Gentile, F.; Coppedè, N.; Coluccio, M.L.; Candeloro, P.; Perozziello, G.; Ferrara, L.; Giannetto, M.; Careri, M.; Castellini, A.; et al. Superhydrophobic lab-on-chip measures secretome protonation state and provides a personalized risk assessment of sporadic tumour. NPJ Precis. Oncol. 2018, 2, 1-13. [CrossRef]

44. Allegretti, M.; Casini, B.; Mandoj, C.; Benini, S.; Alberti, L.; Novello, M.; Melucci, E.; Conti, L.; Covello, R.; Pescarmona, E.; et al. Precision diagnostics of Ewing's sarcoma by liquid biopsy: Circulating EWS-FLI1 fusion transcripts. Ther. Adv. Med Oncol. 2018, 10. [CrossRef]

45. García-Olmo, D.; Olmedillas-López, S.; Cortés-Guiral, D.; Villarejo, P.; López Rojo, I.; Guadalajara, H.; García Gómez-Heras, S.; García-Arranz, M. The role of mucin cell-free DNA detection as a new marker for the study of acellular pseudomyxoma per-itonei of appendicular origin by liquid biopsy. Ther. Adv. Med. Oncol. 2020, 12, 1758835920928233. [CrossRef] [PubMed]

46. Rijavec, E.; Coco, S.; Genova, C.; Rossi, G.; Longo, L. Liquid Biopsy in Non-Small Cell Lung Cancer: Highlights and Challenges. Cancers 2019, 12, 17. [CrossRef] [PubMed]

47. Ko, J.; Carpenter, E.; Issadore, D. Detection and isolation of circulating exosomes and microvesicles for cancer monitoring and diagnostics using micro-/nano-based devices. Analyst 2016, 141, 450-460. [CrossRef] [PubMed]

48. Jung, A.; Kirchner, T. Liquid Biopsy in Tumor Genetic Diagnosis. Dtsch. Aerzteblatt Online 2018, 115, 169-174. [CrossRef]

49. Crowley, E.; Di Nicolantonio, F.; Loupakis, F.; Bardelli, A. Liquid biopsy: Monitoring cancer-genetics in the blood. Nat. Rev. Clin. Oncol. 2013, 10, 472-484. [CrossRef]

50. Diaz, L.; Bardelli, A. Liquid Biopsies: Genotyping Circulating Tumor DNA. J. Clin. Oncol. 2014, 32, 579-586. [CrossRef]

51. Mathai, R.A.; Vidya, R.V.S.; Reddy, B.S.; Thomas, L.; Udupa, K.; Kolesar, J.; Rao, M. Potential Utility of Liquid Biopsy as a Diagnostic and Prognostic Tool for the Assessment of Solid Tumors: Implications in the Precision Oncology. J. Clin. Med. 2019, 8, 373. [CrossRef]

52. Agosti, E.; De Feudis, M.; Angelino, E.; Belli, R.; Alves Teixeira, M.; Zaggia, I.; Tamiso, E.; Raiteri, T.; Scircoli, A.; Ronzoni, F.L.; et al. Both ghrelin deletion and unacylated ghrelin overexpression preserve muscles in aging mice. Aging 2020, 12, 13939-13957. [CrossRef]

53. Fragala, M.S.; Jajtner, A.R.; Beyer, K.S.; Townsend, J.R.; Emerson, N.S.; Scanlon, T.C.; Oliveira, L.P.; Hoffman, J.R.; Stout, J.R. Biomarkers of muscle quality: N-terminal propeptide of type III procollagen and C-terminal agrin fragment responses to resistance exercise training in older adults. J. Cachexia Sarcopenia Muscle 2014, 5, 139-148. [CrossRef] [PubMed]

54. Sheffield-Moore, M.; Dillon, E.L.; Randolph, K.M.; Casperson, S.L.; White, G.R.; Jennings, K.; Rathmacher, J.; Schuette, S.; Janghorbani, M.; Urban, R.J.; et al. Isotopic decay of urinary or plasma 3-methylhistidine as a potential biomarker of pathologic skeletal muscle loss. J. Cachexia Sarcopenia Muscle 2013, 5, 19-25. [CrossRef]

55. Kempf, T.; Eden, M.; Strelau, J.; Naguib, M.; Willenbockel, C.; Tongers, J.; Heineke, J.; Kotlarz, D.; Xu, J.; Molkentin, J.D.; et al. The transforming growth factor-beta superfamily member growth differentiation factor-15 protects the heart from ischemia/reperfusion injury. Circ. Res. 2006, 98, 351-360. [CrossRef] [PubMed]

56. Skog, J.; Würdinger, T.; Van Rijn, S.; Meijer, D.H.; Gainche, L.; Sena-Esteves, M.; Curry, W.T., Jr.; Carter, B.S.; Krichevsky, A.M.; Breakefield, X.O. Glioblastoma microvesicles transport RNA and proteins that promote tumour growth and provide diagnostic biomarkers. Nat. Cell Biol. 2008, 10, 1470-1476. [CrossRef]

57. Taylor, D.D.; Gercel-Taylor, C. MicroRNA signatures of tumor-derived exosomes as diagnostic biomarkers of ovarian cancer. Gynecol. Oncol. 2008, 110, 13-21. [CrossRef]

58. Rabinowits, G.; Gerçel-Taylor, C.; Day, J.M.; Taylor, D.D.; Kloecker, G.H. Exosomal MicroRNA: A Diagnostic Marker for Lung Cancer. Clin. Lung Cancer 2009, 10, 42-46. [CrossRef] [PubMed]

59. Mandel, P.; Metais, P. Les acides nucléiques du plasma sanguin chez l'homme. CR Seances Soc. Biol. Fil. 1948, 142, $241-243$. 
60. Griffiths-Jones, S.; Saini, H.K.; van Dongen, S.; Enright, A.J. Mirbase: Tools for microRNA genomics. Nucleic Acids Res. 2008, 36, D154-D158. [CrossRef] [PubMed]

61. Lee, R.C.; Ambros, V. An extensive class of small RNAs in Caenorhabditis elegans. Science 2001, 294, 862-886. [CrossRef] [PubMed]

62. Moran, Y.; Agron, M.; Praher, D.; Technau, U. The evolutionary origin of plant and animal microRNAs. Nat. Ecol. Evol. 2017, 1, 1-8. [CrossRef] [PubMed]

63. Pasquinelli, A.E.; Reinhart, B.J.; Slack, F.; Martindale, M.Q.; Kuroda, M.I.; Maller, B.; Hayward, D.C.; Ball, E.E.; Degnan, B.; Müller, P.; et al. Conservation of the sequence and temporal expression of let-7 heterochronic regulatory RNA. Nature 2000, 408, 86-89. [CrossRef]

64. Zhang, A.; Zhang, J.; Kaipainen, A.; Jared MLucas, J.M.; Yang, H. Long non-coding RNA: A newly deciphered "code" in prostate cancer. Cancer Lett. 2016, 375, 323-330. [CrossRef]

65. Casey, M.; Sweeney, K.J.; Brown, J.A.L.; Kerin, M.J. Exploring circulating micro- RNA in the neoadjuvant treatment of breast cancer. Int. J. Cancer 2016, 139, 12-22. [CrossRef] [PubMed]

66. Ali, S.; Suresh, R.; Banerjee, S.; Bao, B.; Xu, Z.; Wilson, J.; Philip, P.A.; Apte, M.; Sarkar, F.H. Contribution of microRNAs in under-standing the pancreatic tumor microenvironment involving cancer associated stellate and fibroblast cells. Am. J. Cancer Res. 2015, 5, 1251-1264.

67. Schwarzenbach, H.; Hoon, D.S.B.; Pantel, K. Cell-free nucleic acids as biomarkers in cancer patients. Nat. Rev. Cancer 2011, 11, 426-437. [CrossRef] [PubMed]

68. Mehra, N.; Penning, M.; Maas, J.; Van Daal, N.; Giles, R.H.; Voest, E.E. Circulating Mitochondrial Nucleic Acids Have Prognostic Value for Survival in Patients with Advanced Prostate Cancer. Clin. Cancer Res. 2007, 13, 421-426. [CrossRef]

69. Finotti, A.; Allegretti, M.; Gasparello, J.; Giacomini, P.; Spandidos, D.A.; Spoto, G.; Gambari, R. Liquid biopsy and PCR-free ultra-sensitive detection systems in oncology (Review). Int. J. Oncol. 2018, 53, 1395-1434.

70. Soares, R.J.R.; Cagnin, S.; Chemello, F.; Silvestrin, M.; Musaro, A.; De Pitta, C.; Lanfranchi, G.; Sandri, M. Involvement of MicroRNAs in the Regulation of Muscle Wasting during Catabolic Conditions. J. Biol. Chem. 2014, 289, 21909-21925. [CrossRef] [PubMed]

71. Lee, D.E.; Brown, J.L.; Rosa-Caldwell, M.E.; Blackwell, T.A.; Perry, R.A., Jr.; Brown, L.A.; Khatri, B.; Seo, D.; Bottje, W.G.; Washington, T.A.; et al. Cancer cachexia-induced muscle atrophy: Evidence for alterations in microRNAs important for muscle size. Physiol. Genom. 2017, 49, 253-260. [CrossRef] [PubMed]

72. Moraes, L.N.; Fernandez, G.J.; Vechetti-Júnior, I.J.; Freire, P.P.; Souza, R.W.A.; Villacis, R.A.R.; Rogatto, S.R.; Reis, P.P.; Dal-Pai-Silva, M.; Carvalho, R.F. Integration of miRNA and mRNA expression profiles reveals microRNA-regulated networks during muscle wasting in cardiac cachexia. Sci. Rep. 2017, 7, 6998. [CrossRef]

73. He, W.A.; Calore, F.; Londhe, P.; Canella, A.; Guttridge, D.C.; Croce, C.M. Microvesicles containing miRNAs promote muscle cell death in cancer cachexia via TLR7. Proc. Natl. Acad. Sci. USA 2014, 111, 4525-4529. [CrossRef]

74. Mitchell, P.S.; Parkin, R.K.; Kroh, E.M.; Fritz, B.R.; Wyman, S.K.; Pogosova-Agadjanyan, E.L.; Peterson, A.; Noteboom, J.; O’Briant, K.C.; Allen, A.; et al. Circulating microRNAs as stable blood-based markers for cancer detection. Proc. Natl. Acad. Sci. USA 2008, 105, 10513-10518. [CrossRef] [PubMed]

75. Chim, S.S.; Shing, T.K.; Hung, E.C.; Leung, T.Y.; Lau, T.K.; Chiu, R.W.; Lo, Y.M. Detection and characterization of placental mi-croRNAs in maternal plasma. Clin. Chem. 2008, 54, 482-490. [CrossRef] [PubMed]

76. Ge, Q.; Zhou, Y.; Lu, J.; Bai, Y.; Xie, X.; Lu, Z. miRNA in Plasma Exosome is Stable under Different Storage Conditions. Molecules 2014, 19, 1568-1575. [CrossRef] [PubMed]

77. De Rie, D.; Abugessaisa, I.; Alam, T.; Arner, E.; Arner, P.; Ashoor, H.; Åström, G.; Babina, M.; Bertin, N.; Burroughs, A.M.; et al. An integrated expression atlas of miRNAs and their promoters in human and mouse. Nat. Biotechnol. 2017, 35, 872-878. [CrossRef]

78. Kim, Y.K.; Kim, V.N. Processing of intronic microRNAs. EMBO J. 2007, 26, 775-783. [CrossRef] [PubMed]

79. Ha, M.; Kim, V.N. Regulation of microRNA biogenesis. Nat. Rev. Mol. Cell Biol. 2014, 15, 509-524. [CrossRef]

80. Tanzer, A.; Stadler, P.F. Molecular evolution of a microRNA cluster. J. Mol. Biol. 2004, 339, 327-335. [CrossRef] [PubMed]

81. Wang, Y.; Zhang, X.; Li, H.; Yu, J.; Ren, X. The role of miRNA-29 family in cancer. Eur. J. Cell Biol. 2013, 92, 123-128. [CrossRef] [PubMed]

82. Wang, R.; Wen, H.; Xu, Y.; Chen, Q.; Luo, Y.; Lin, Y.; Luo, Y.; Xu, A. Circulating microRNAs as a novel class of diagnostic bi-omarkers in gastrointestinal tumors detection: A meta-analysis based on 42 articles. PLoS ONE 2014, 9, e113401.

83. Denli, A.M.; Tops, B.; Plasterk, R.H.A.; Ketting, R.F.; Hannon, G.J. Processing of primary microRNAs by the Microprocessor complex. Nat. Cell Biol. 2004, 432, 231-235. [CrossRef]

84. O'Brien, J.; Hayder, H.; Zayed, Y.; Peng, C. Overview of MicroRNA Biogenesis, Mechanisms of Actions, and Circulation. Front. Endocrinol. 2018, 9, 402. [CrossRef]

85. Czech, B.; Zhou, R.; Erlich, Y.; Brennecke, J.; Binari, R.; Villalta, C.; Gordon, A.; Perrimon, N.; Hannon, G.J. Hierarchical Rules for Argonaute Loading in Drosophila. Mol. Cell 2009, 36, 445-456. [CrossRef] [PubMed]

86. Hu, H.Y.; Yan, Z.; Xu, Y.; Hu, H.; Menzel, C.; Zhou, Y.H.; Chen, W.; Khaitovich, P. Sequence features associated with microRNA strand selection in humans and flies. BMC Genom. 2009, 10, 1-11. [CrossRef] [PubMed]

87. Okamura, K.; Liu, N.; Lai, E.C. Distinct Mechanisms for MicroRNA Strand Selection by Drosophila Argonautes. Mol. Cell 2009, 36, 431-444. [CrossRef] 
88. Finnegan, E.F.; Pasquinelli, A.E. MicroRNA biogenesis: Regulating the regulators. Crit. Rev. Biochem. Mol. Biol. 2013, 48, 51-68. [CrossRef] [PubMed]

89. Zhang, Z.; Qin, Y.-W.; Brewer, G.; Jing, Q. MicroRNA degradation and turnover: Regulating the regulators. Wiley Interdiscip. Rev. RNA 2012, 3, 593-600. [CrossRef]

90. Broughton, J.; Lovci, M.T.; Huang, J.L.; Yeo, E.; Pasquinelli, A.E. Pairing beyond the Seed Supports MicroRNA Targeting Specificity. Mol. Cell 2016, 64, 320-333. [CrossRef] [PubMed]

91. Ambros, V. The functions of animal microRNAs. Nature 2004, 431, 350-355. [CrossRef]

92. Dharap, A.; Pokrzywa, C.; Murali, S.; Pandi, G.; Vemuganti, R. MicroRNA miR-324-3p Induces Promoter-Mediated Expression of RelA Gene. PLoS ONE 2013, 8, e79467. [CrossRef]

93. Huan, J.; Hornick, N.I.; Shurtleff, M.J.; Skinner, A.M.; Goloviznina, N.A.; Roberts, C.T., Jr.; Kurre, P. RNA trafficking by acute mye-logenous leukemia exosomes. Cancer Res. 2013, 73, 918-929. [CrossRef] [PubMed]

94. Akers, J.C.; Gonda, D.; Kim, R.; Carter, B.S.; Chen, C.C. Biogenesis of extracellular vesicles (EV): Exosomes, microvesicles, retrovirus-like vesicles, and apoptotic bodies. J. Neuro Oncol. 2013, 113, 1-11. [CrossRef]

95. Colombo, M.; Raposo, G.; Théry, C. Biogenesis, secretion, and intercellular interactions of exosomes and other extracellular vesicles. Annu. Rev. Cell Dev. Biol. 2014, 30, 255-289. [CrossRef] [PubMed]

96. Théry, C.; Witwer, K.W.; Aikawa, E.; Alcaraz, M.J.; Anderson, J.D.; Andriantsitohaina, R.; Antoniou, A.; Arab, T.; Archer, F.; Atkin-Smith, G.K.; et al. Minimal information for studies of extracellular vesicles 2018 (MISEV2018): A position statement of the International Society for Extracellular Vesicles and update of the MISEV2014 guidelines. J. Extracell Vesicles 2018, 7, 1535750. [CrossRef] [PubMed]

97. Trovato, E.; Di Felice, V.; Barone, R. Extracellular Vesicles: Delivery Vehicles of Myokines. Front. Physiol. 2019, 10, 522. [CrossRef] [PubMed]

98. Wang, Y.; Wang, Q.; Wei, X.; Shao, J.; Zhao, J.; Zhang, Z.; Chen, Z.; Bai, Y.; Wang, N.; Wang, Y.; et al. Global scientific trends on exosome research during 2007-2016: A bibliometric analysis. Oncotarget 2017, 8, 48460-48470. [CrossRef]

99. Masaoutis, C.; Mihailidou, C.; Tsourouflis, G.; Theocharis, S. Exosomes in lung cancer diagnosis and treatment. From the translating research into future clinical practice. Biochimie 2018, 151, 27-36. [CrossRef]

100. Willms, E.; Cabañas, C.; Mäger, I.; Wood, M.J.A.; Vader, P. Extracellular Vesicle Heterogeneity: Subpopulations, Isolation Techniques, and Diverse Functions in Cancer Progression. Front. Immunol. 2018, 9, 738. [CrossRef]

101. Turturici, G.; Tinnirello, R.; Sconzo, G.; Geraci, F. Extracellular membrane vesicles as a mechanism of cell-to-cell communication: Advantages and disadvantages. Am. J. Physiol. Physiol. 2014, 306, C621-C633. [CrossRef]

102. Cocucci, E.; Meldolesi, J. Ectosomes and exosomes: Shedding the confusion between extracellular vesicles. Trends Cell Biol. 2015, 25, 364-372. [CrossRef]

103. Atkin-Smith, G.K.; Tixeira, R.; Paone, S.; Mathivanan, S.; Collins, C.; Liem, M.; Goodall, K.; Ravichandran, K.; Hulett, M.; Poon, I.K. A novel mechanism of generating extracellular vesicles during apoptosis via a beads-on-a-string membrane structure. Nat. Commun. 2015, 6, 7439. [CrossRef]

104. Coleman, M.L.; Sahai, E.A.; Yeo, M.; Bosch, M.; Dewar, A.; Olson, M.F. Membrane blebbing during apoptosis results from caspa-se-mediated activation of ROCK I. Nat. Cell Biol. 2001, 3, 339-345. [CrossRef]

105. Hergenreider, E.; Heydt, S.; Trèguer, K.; Boettger, T.; Horrevoets, A.J.G.; Zeiher, A.M.; Scheffer, M.P.; Frangakis, A.S.; Yin, X.; Mayr, M.; et al. Athero protective communication between endothelial cells and smooth muscle cells through miRNAs. Nat. Cell Biol. 2012, 14, 249-256. [CrossRef] [PubMed]

106. Zhang, Y.; Liu, D.; Chen, X.; Li, J.; Li, L.; Bian, Z.; Sun, F.; Lu, J.; Yin, Y.; Cai, X.; et al. Secreted Monocytic miR-150 Enhances Targeted Endothelial Cell Migration. Mol. Cell 2010, 39, 133-144. [CrossRef]

107. Mittelbrunn, M.; Sánchez-Madrid, F. Intercellular communication: Diverse structures for exchange of genetic information. Nat. Rev. Mol. Cell Biol. 2012, 13, 328-335. [CrossRef]

108. Iftikhar, H.; Carney, G.E. Evidence and potential in vivo functions for biofluid miRNAs: From expression profiling to functional testing: Potential roles of extracellular miRNAs as indicators of physiological change and as agents of intercellular information exchange. Bioessays 2016, 38, 367-378. [CrossRef]

109. Cortez, M.A.; Bueso-Ramos, C.; Ferdin, J.; Lopez-Berestein, L.; Sood, A.K.; Calin, G.A. MicroRNAs in body fluids-the mix of hor-mones and biomarkers. Nat. Rev. Clin. Oncol. 2011, 8, 467-477. [CrossRef]

110. Garzon, R.; Garofalo, M.; Martelli, M.P.; Briesewitz, R.; Wang, L.; Fernandez-Cymering, C.; Volinia, S.; Liu, C.-G.; Schnittger, S.; Haferlach, T.; et al. Distinctive microRNA signature of acute myeloid leukemia bearing cytoplasmic mutated nucleophosmin. Proc. Natl. Acad. Sci. USA 2008, 105, 3945-3950. [CrossRef] [PubMed]

111. Turchinovich, A.; Weiz, L.; Burwinkel, B. Extracellular miRNAs: The mystery of their origin and function. Trends Biochem. Sci. 2012, 37, 460-465. [CrossRef]

112. Vickers, K.C.; Palmisano, B.T.; Shoucri, B.M.; Shamburek, R.D.; Remaley, A.T. MicroRNAs are transported in plasma and delivered to recipient cells by high-density lipoproteins. Nat. Cell Biol. 2011, 13, 423-433. [CrossRef] [PubMed]

113. Tabet, F.; Vickers, K.C.; Torres, L.F.C.; Wiese, C.; Shoucri, B.M.; Lambert, G.; Catherinet, C.; Prado-Lourenco, L.; Levin, M.; Thacker, S.; et al. HDL-transferred microRNA-223 regulates ICAM-1 expression in endothelial cells. Nat. Commun. 2014, 5, 1-14. [CrossRef]

114. Michell, D.L.; Vickers, K.C. Lipoprotein carriers of microRNAs. Biochim. Biophys. Acta 2016, 1861, 2069-2074. [CrossRef] [PubMed] 
115. Turchinovich, A.; Samatov, T.R.; Tonevitsky, A.G.; Burwinkel, B. Circulating miRNAs: Cell-cell communication function? Front. Genet. 2013, 4, 119. [CrossRef] [PubMed]

116. Chen, X.; Liang, H.; Zhang, J.; Zen, K.; Zhang, C.-Y. Secreted microRNAs: A new form of intercellular communication. Trends Cell Biol. 2012, 22, 125-132. [CrossRef]

117. Aucher, A.; Rudnicka, D.; Davis, D.M. MicroRNAs Transfer from Human Macrophages to Hepato-Carcinoma Cells and Inhibit Proliferation. J. Immunol. 2013, 191, 6250-6260. [CrossRef]

118. Turchinovich, A.; Weiz, L.; Langheinz, A.; Burwinkel, B. Characterization of extracellular circulating microRNA. Nucleic Acids Res. 2011, 39, 7223-7233. [CrossRef] [PubMed]

119. Thomas, M.J.; Fraser, D.J.; Bowen, T. Biogenesis, Stabilization, and Transport of microRNAs in Kidney Health and Disease. Non-Coding RNA 2018, 4, 30. [CrossRef]

120. Valadi, H.; Ekström, K.; Bossios, A.; Sjöstrand, M.; Lee, J.J.; Lötvall, J.O. Exosome-mediated transfer of mRNAs and microRNAs is a novel mechanism of genetic exchange between cells. Nat. Cell Biol. 2007, 9, 654-659. [CrossRef] [PubMed]

121. Teplyuk, N.M.; Mollenhauer, B.; Gabriely, G.; Giese, A.; Kim, E.; Smolsky, M.; Kim, R.Y.; Saria, M.G.; Pastorino, S.; Kesari, S.; et al. MicroRNAs in cerebrospinal fluid identify glioblastoma and metastatic brain cancers and reflect disease ac-tivity. Neuro Oncol. 2012, 14, 689-700. [CrossRef] [PubMed]

122. Kosaka, N.; Iguchi, H.; Yoshioka, Y.; Takeshita, F.; Matsuki, Y.; Ochiya, T. Secretory mechanisms and intercellular transfer of MicroRNAs in living cells. J. Biol. Chem. 2010, 285, 17442-17452. [CrossRef]

123. Wang, K.; Zhang, S.; Weber, J.; Baxter, D.; Galas, D.J. Export of microRNAs and microRNA-protective protein by mammalian cells. Nucleic Acids Res. 2010, 38, 7248-7259. [CrossRef]

124. Yang, M.; Chen, J.; Su, F.; Yu, B.; Su, F.; Lin, L.; Liu, Y.; Huang, J.D.; Song, E. Microvesicles secreted by macrophages shuttle inva-sion-potentiating microRNAs into breast cancer cells. Mol. Cancer 2011, 10, 117. [CrossRef] [PubMed]

125. Hannafon, B.N.; Carpenter, K.J.; Berry, W.L.; Janknecht, R.; Dooley, W.C.; Ding, W.-Q. Exosome-mediated microRNA signaling from breast cancer cells is altered by the anti-angiogenesis agent docosahexaenoic acid (DHA). Mol. Cancer 2015, 14, 1-13. [CrossRef] [PubMed]

126. Wang, H.; Wang, B. Extracellular vesicle microRNAs mediate skeletal muscle myogenesis and disease. Biomed. Rep. 2016, 5, 296-300. [CrossRef] [PubMed]

127. Penna, F.; Ballarò, R.; Beltrà, M.; De Lucia, S.; Castillo, L.G.; Costelli, P. The Skeletal Muscle as an Active Player Against Cancer Cachexia. Front. Physiol. 2019, 10, 41. [CrossRef] [PubMed]

128. Penna, F.; Ballarò, R.; Cristobal, P.M.; Sala, D.; Sebastian, D.; Busquets, S.; Muscaritoli, M.; Argiles, J.M.; Costelli, P.; Zorzano, A. Autophagy Exacerbates Muscle Wasting in Cancer Cachexia and Impairs Mitochondrial Function. J. Mol. Biol. 2019, 431, 2674-2686. [CrossRef] [PubMed]

129. Gatta, L.; Vitiello, L.; Gorini, S.; Chiandotto, S.; Costelli, P.; Giammarioli, A.M.; Malorni, W.; Rosano, G.; Ferraro, E. Modulating the metabolism by trimetazidine enhances myoblast differentiation and promotes myogenesis in cachectic tumor-bearing c26 mice. Oncotarget 2017, 8, 113938-113956. [CrossRef] [PubMed]

130. Margolis, L.; Rivas, D.A.; Pasiakos, S.M.; McClung, J.P.; Ceglia, L.; Fielding, R.A. Upregulation of circulating myomiR following short-term energy restriction is inversely associated with whole body protein synthesis. Am. J. Physiol. Integr. Comp. Physiol. 2017, 313, R298-R304. [CrossRef] [PubMed]

131. Donzelli, S.; Farneti, A.; Marucci, L.; Ganci, F.; Sacconi, A.; Strano, S.; Sanguineti, G.; Blandino, G. Non-coding RNAs as Putative Biomarkers of Cancer-Associated Cachexia. Front. Cell Dev. Biol. 2020, 8, 257. [CrossRef]

132. Whysall, K.; Sweetman, D.; Munsterberg, A. microRNAs in skeletal muscle differentiation and disease. Clin. Sci. 2012, 123, 611-625. [CrossRef]

133. McCarthy, J.J. The MyomiR Network in Skeletal Muscle Plasticity. Exerc. Sport Sci. Rev. 2011, 39, 150-154. [CrossRef]

134. Tan, L.-J.; Liu, S.-L.; Lei, S.-F.; Papasian, C.J.; Deng, H. Molecular genetic studies of gene identification for sarcopenia. Hum. Genet. 2011, 131, 1-31. [CrossRef]

135. Ge, Y.; Chen, J. MicroRNAs in skeletal myogenesis. Cell Cycle 2011, 10, 441-448. [CrossRef] [PubMed]

136. Yu, X.K.; Zuo, Q. MicroRAs in the regeneration of skeletal muscle. Front. Biosci. 2013, 18, 608-615. [CrossRef] [PubMed]

137. Güller, I.; Russell, A.P. MicroRNAs in skeletal muscle: Their role and regulation in development, disease and function. J. Physiol. 2010, 588, 4075-4087. [CrossRef]

138. Kim, V.N.; Nam, J.-W. Genomics of microRNA. Trends Genet. 2006, 22, 165-173. [CrossRef]

139. Liu, N.; Williams, A.H.; Kim, Y.; McAnally, J.; Bezprozvannaya, S.; Sutherland, L.B.; Richardson, J.A.; Bassel-Duby, R.; Olson, E.N. An intragenic MEF2-dependent enhancer directs muscle-specific expression of microRNAs 1 and 133. Proc. Natl. Acad. Sci. USA 2007, 104, 20844-20849. [CrossRef] [PubMed]

140. Rao, P.K.; Kumar, R.M.; Farkhondeh, M.; Baskerville, S.; Lodish, H.F. Myogenic factors that regulate expression of muscle-specific microRNAs. Proc. Natl. Acad. Sci. USA 2006, 103, 8721-8726. [CrossRef]

141. Sweetman, D.; Goljanek, K.; Rathjen, T.; Oustanina, S.; Braun, T.; Dalmay, T.; Münsterberg, A. Specific requirements of MRFs for the expression of muscle specific microRNAs, miR-1, miR-206 and miR-133. Dev. Biol. 2008, 321, 491-499. [CrossRef]

142. Yeung, F.; Chung, E.; Guess, M.; Bell, M.L.; Leinwand, L.A. Myh7b/miR-499 gene expression is transcriptionally regulated by MRFs and Eos. Nucleic Acids Res. 2012, 40, 7303-7318. [CrossRef] 
143. Hudson, M.B.; Rahnert, J.A.; Zheng, B.; Woodworth-Hobbs, M.E.; Franch, H.A.; Price, S.R. miR-182 attenuates atrophy-related gene expression by targeting FoxO3 in skeletal muscle. Am. J. Physiol. Physiol. 2014, 307, C314-C319. [CrossRef]

144. Narasimhan, A.; Ghosh, S.; Stretch, C.; Greiner, R.; Bathe, O.F.O.F.; Baracos, V.; Damaraju, S. Small RNAome profiling from human skeletal muscle: Novel miRNAs and their targets associated with cancer cachexia. J. Cachexia Sarcopenia Muscle 2017, 8 , 405-416. [CrossRef] [PubMed]

145. Nie, M.; Deng, Z.-L.; Liu, J.; Wang, D.-Z. Noncoding RNAs, Emerging Regulators of Skeletal Muscle Development and Diseases. BioMed Res. Int. 2015, 2015, 676575. [CrossRef] [PubMed]

146. Aoi, W.; Sakuma, K. Does regulation of skeletal muscle function involve circulating microRNAs? Front. Physiol. 2014, 5, 39. [CrossRef]

147. Siracusa, J.; Koulmann, N.; Banzet, S. Circulating myomiRs: A new class of biomarkers to monitor skeletal muscle in physiology and medicine. J. Cachexia Sarcopenia Muscle 2017, 9, 20-27. [CrossRef] [PubMed]

148. Hitachi, K.; Nakatani, M.; Tsuchida, K. Myostatin signaling regulates Akt activity via the regulation of miR-486 expression. Int. J. Biochem. Cell Biol. 2014, 47, 93-103. [CrossRef]

149. Hitachi, K.; Tsuchida, K. Role of microRNAs in skeletal muscle hypertrophy. Front. Physiol. 2014, 4, 408. [CrossRef]

150. Shi, Q.; Yang, X. Circulating MicroRNA and Long Noncoding RNA as Biomarkers of Cardiovascular Diseases. J. Cell. Physiol. 2016, 231, 751-755. [CrossRef]

151. Vegter, E.L.; Van Der Meer, P.; De Windt, L.J.; Pinto, Y.M.; Voors, A.A. MicroRNAs in heart failure: From biomarker to target for therapy. Eur. J. Hear. Fail. 2016, 18, 457-468. [CrossRef]

152. Cacchiarelli, D.; Martone, J.; Girardi, E.; Cesana, M.; Incitti, T.; Morlando, M.; Nicoletti, C.; Santini, T.; Sthandier, O.; Barberi, L.; et al. MicroRNAs Involved in Molecular Circuitries Relevant for the Duchenne Muscular Dystrophy Pathogenesis Are Controlled by the Dystrophin/nNOS Pathway. Cell Metab. 2010, 12, 341-351. [CrossRef]

153. Liu, Y.; Li, M.; Ma, J.; Zhang, J.; Zhou, C.; Wang, T.; Gao, X.; Li, X. Identification of differences in microRNA transcriptomes between porcine oxidative and glycolytic skeletal muscles. BMC Mol. Biol. 2013, 14, 1-8. [CrossRef] [PubMed]

154. Muroya, S.; Taniguchi, M.; Shibata, M.; Oe, M.; Ojima, K.; Nakajima, I.; Chikuni, K. Profiling of differentially expressed microRNA and the bioinformatic target gene analyses in bovine fast- and slow-type muscles by massively parallel sequencing1. J. Anim. Sci. 2013, 91, 90-103. [CrossRef] [PubMed]

155. Fearon, K.C.; Glass, D.J.; Guttridge, D.C. Cancer Cachexia: Mediators, Signaling, and Metabolic Pathways. Cell Metab. 2012, 16, 153-166. [CrossRef]

156. Schiaffino, S.; Dyar, K.; Ciciliot, S.; Blaauw, B.; Sandri, M. Mechanisms regulating skeletal muscle growth and atrophy. FEBS J. 2013, 280, 4294-4314. [CrossRef]

157. Kukreti, H.; Amuthavalli, K.; Harikumar, A.; Sathiyamoorthy, S.; Feng, P.Z.; Anantharaj, R.; Tan, S.L.K.; Lokireddy, S.; Bonala, S.; Sriram, S.; et al. Muscle-specific MicroRNA1 (miR1) Targets Heat Shock Protein 70 (HSP70) during Dexamethasone-mediated Atrophy. J. Biol. Chem. 2013, 288, 6663-6678. [CrossRef] [PubMed]

158. Cacchiarelli, D.; Legnini, I.; Martone, J.; Cazzella, V.; D’Amico, A.; Bertini, E.; Bozzoni, I. miRNAs as serum biomarkers for Duchenne muscular dystrophy. EMBO Mol. Med. 2011, 3, 258-265. [CrossRef] [PubMed]

159. Köberle, V.; Kronenberger, B.; Pleli, T.; Trojan, J.; Imelmann, E.; Peveling-Oberhag, J.; Welker, M.W.; Elhendawy, M.; Zeuzem, S.; Piiper, A.; et al. Serum microRNA-1 and microRNA-122 are prognostic markers in patients with hepatocellular car-cinoma. Eur. J. Cancer 2013, 49, 3442-3449. [CrossRef] [PubMed]

160. Chen, J.-F.; Tao, Y.; Li, J.; Deng, Z.; Yan, Z.; Xiao, X.; Wang, D.-Z. microRNA-1 and microRNA-206 regulate skeletal muscle satellite cell proliferation and differentiation by repressing Pax7. J. Cell Biol. 2010, 190, 867-879. [CrossRef]

161. Olguin, H.C.; Yang, Z.; Tapscott, S.J.; Olwin, B.B. Reciprocal inhibition between Pax7 and muscle regulatory factors modulates myogenic cell fate determination. J. Cell Biol. 2007, 177, 769-779. [CrossRef]

162. Rosenberg, M.I.; Georges, S.A.; Asawachaicharn, A.; Analau, E.; Tapscott, S.J. MyoD inhibits Fstl1 and Utrn expression by inducing transcription of miR-206. J. Cell Biol. 2006, 175, 77-85. [CrossRef] [PubMed]

163. Lee, E.J.; Baek, M.; Gusev, Y.; Brackett, D.J.; Nuovo, G.J.; Schmittgen, T.D. Systematic evaluation of microRNA processing patterns in tissues, cell lines, and tumors. RNA 2007, 14, 35-42. [CrossRef] [PubMed]

164. Xu, J.; Li, R.; Workeneh, B.; Dong, Y.; Wang, X.; Hu, Z. Transcription factor FoxO1, the dominant mediator of muscle wasting in chronic kidney disease, is inhibited by microRNA-486. Kidney Int. 2012, 82, 401-411. [CrossRef] [PubMed]

165. Small, E.M.; O’Rourke, J.R.; Moresi, V.; Sutherland, L.B.; McAnally, J.; Gerard, R.D.; Richardson, J.A.; Olson, E.N. Regulation of PI3-kinase/Akt signaling by muscle-enriched microRNA-486. Proc. Natl. Acad. Sci. USA 2010, 107, 4218-4223. [CrossRef] [PubMed]

166. Cohen, A.; Zinger, A.; Tiberti, N.; Grau, G.E.R.; Combes, V. Differential plasma microvesicle and brain profiles of microRNA in experimental cerebral malaria. Malar. J. 2018, 17, 192. [CrossRef]

167. ElKhouly, A.; Youness, R.A.; Gad, M.Z. MicroRNA-486-5p and microRNA-486-3p: Multifaceted pleiotropic mediators in oncological and non-oncological conditions. Noncoding RNA Res. 2020, 5, 11-21. [CrossRef] [PubMed]

168. Van de Worp, W.R.P.; Theys, J.; van Helvoort, A.; Langen, R.C.J. Regulation of muscle atrophy by microRNAs: 'AtromiRs' as po-tential target in cachexia. Curr. Opin. Clin. Nutr. Metab. Care 2018, 21, 423-429. [CrossRef] [PubMed] 
169. Van De Worp, W.R.; Schols, A.M.; Dingemans, A.C.; Kamp, C.M.O.D.; Degens, J.H.; Kelders, M.C.; Coort, S.; Woodruff, H.C.; Kratassiouk, G.; Harel-Bellan, A.; et al. Identification of microRNAs in skeletal muscle associated with lung cancer cachexia. J. Cachexia Sarcopenia Muscle 2020, 11, 452-463. [CrossRef] [PubMed]

170. Chevillet, J.R.; Kang, Q.; Ruf, I.K.; Briggs, H.A.; Vojtech, L.N.; Hughes, S.M.; Cheng, H.H.; Arroyo, J.D.; Meredith, E.K.; Gallichotte, E.N.; et al. Quantitative and stoi-chiometric analysis of the microRNA content of exosomes. Proc. Natl. Acad. Sci. USA 2014, 111, 14888-14893. [CrossRef]

171. Kirby, T.; McCarthy, J.J. MicroRNAs in skeletal muscle biology and exercise adaptation. Free. Radic. Biol. Med. 2013, 64, 95-105. [CrossRef]

172. Durham, W.J.; Dillon, E.L.; Sheffield-Moore, M. Inflammatory burden and amino acid metabolism in cancer cachexia. Curr. Opin. Clin. Nutr. Metab. Care 2009, 12, 72-77. [CrossRef]

173. Garros, R.F.; Paul, R.; Connolly, M.; Lewis, A.; Garfield, B.E.; Natanek, S.A.; Bloch, S.; Mouly, V.; Griffiths, M.J.; Polkey, M.I.; et al. MicroRNA-542 Promotes Mitochondrial Dysfunction and SMAD Activity and Is Elevated in Intensive Care Unit-acquired Weakness. Am. J. Respir. Crit. Care Med. 2017, 196, 1422-1433. [CrossRef]

174. Connolly, M.; Paul, R.; Farre-Garros, R.; Natanek, S.A.; Bloch, S.; Lee, J.; Lorenzo, J.P.; Patel, H.; Cooper, C.; Sayer, A.A.; et al. miR-424-5p reduces ribosomal RNA and protein synthesis in muscle wasting. J. Cachexia Sarcopenia Muscle 2018, 9, 400-416. [CrossRef]

175. de Andrade, H.M.; de Albuquerque, M.; Avansini, S.; Rocha, C.D.S.; Dogini, D.; Nucci, A.; Carvalho, B.; Lopes-Cendes, I.; França, M.C. MicroRNAs-424 and 206 are potential prognostic markers in spinal onset amyotrophic lateral sclerosis. J. Neurol. Sci. 2016, 368, 19-24. [CrossRef] [PubMed]

176. Kovanda, A.; Leonardis, L.; Zidar, J.; Koritnik, B.; Dolenc-Groselj, L.; Kovacic, S.R.; Curk, T.; Rogelj, B. Differential expression of microRNAs and other small RNAs in muscle tissue of patients with ALS and healthy age-matched controls. Sci. Rep. 2018, 8, 1-15. [CrossRef] [PubMed]

177. Jia, L.; Li, Y.F.; Wu, G.F.; Song, Z.Y.; Lu, H.Z.; Song, C.C.; Zhang, Q.L.; Zhu, J.Y.; Yang, G.S.; Shi, X.E. MiRNA-199a-3p regulates C2C12 myoblast differentiation through IGF-1/AKT/mTOR signal pathway. Int. J. Mol. Sci. 2013, 15, 296-308. [CrossRef] [PubMed]

178. Lecker, S.H.; Jagoe, R.T.; Gilbert, A.; Gomes, M.; Baracos, V.; Bailey, J.; Price, S.R.; Mitch, W.E.; Goldberg, A.L. Multiple types of skeletal muscle atrophy involve a common program of changes in gene expression. FASEB J. 2003, 18, 39-51. [CrossRef]

179. Chandran, S.; Guo, T.; Tolliver, T.; Chen, W.; Murphy, D.L.; McPherron, A.C. Effects of serotonin on skeletal muscle growth. BMC Proc. 2012, 6, O3. [CrossRef]

180. Dwarkasing, J.T.; Boekschoten, M.; Argiles, J.M.; Van Dijk, M.; Busquets, S.; Penna, F.; Toledo, M.; Laviano, A.; Witkamp, R.; Van Norren, K. Differences in food intake of tumour-bearing cachectic mice are associated with hypothalamic serotonin signalling. J. Cachexia Sarcopenia Muscle 2015, 6, 84-94. [CrossRef]

181. Drummond, M.J.; Glynn, E.L.; Fry, C.S.; Dhanani, S.; Volpi, E.; Rasmussen, B.B. Essential Amino Acids Increase MicroRNA-499, -208b, and -23a and Downregulate Myostatin and Myocyte Enhancer Factor 2C mRNA Expression in Human Skeletal Muscle. J. Nutr. 2009, 139, 2279-2284. [CrossRef] [PubMed]

182. Santos, J.M.O.; Peixoto da Silva, S.; Gil da Costa, R.M.; Medeiros, R. The Emerging Role of MicroRNAs and Other Non-Coding RNAs in Cancer Cachexia. Cancers 2020, 12, 1004. [CrossRef] [PubMed]

183. Fang, Z.; Dai, W.; Wang, X.; Chen, W.; Shen, C.; Ye, G.; Li, L. Circulating miR-205: A promising biomarker for the detection and prognosis evaluation of bladder cancer. Tumor Biol. 2015, 37, 8075-8082. [CrossRef]

184. Zheng, M.; Hou, L.; Ma, Y.; Zhou, L.; Wang, F.; Cheng, B.; Wang, W.; Lu, B.; Liu, P.; Lu, W.; et al. Exosomal let-7d-3p and miR-30d-5p as diagnostic biomarkers for non-invasive screening of cervical cancer and its precursors. Mol. Cancer 2019, 18, 1-8. [CrossRef]

185. Erener, S.; Marwaha, A.; Tan, R.; Panagiotopoulos, C.; Kieffer, T.J. Profiling of circulating microRNAs in children with recent onset of type 1 diabetes. JCI Insight 2017, 2, e89656. [CrossRef] [PubMed]

186. Miyamoto, S.; Usami, S.; Kuwabara, Y.; Horie, T.; Baba, O.; Hakuno, D.; Nakashima, Y.; Nishiga, M.; Izuhara, M.; Nakao, T.; et al Expression Patterns of miRNA-423-5p in the Serum and Pericardial Fluid in Patients Undergoing Cardiac Surgery. PLoS ONE 2015, 10, e0142904. [CrossRef] [PubMed]

187. Yu, F.; Wang, X.; Zhao, H.; Hao, Y.; Wang, W. Decreased Serum miR-1296 may Serve as an Early Biomarker for the Diagnosis of Non-Alcoholic Fatty Liver Disease. Clin. Lab. 2019, 65. [CrossRef]

188. Su, M.; Niu, Y.; Dang, Q.; Qu, J.; Zhu, D.; Tang, Z.; Gou, D. Circulating microRNA profiles based on direct S-Poly(T)Plus assay for detection of coronary heart disease. J. Cell. Mol. Med. 2020, 24, 5984-5997. [CrossRef] [PubMed]

189. Zhao, H.; Wang, J.; Gao, L.; Wang, R.; Liu, X.; Gao, Z.; Tao, Z.; Xu, C.; Song, J.; Ji, X.; et al. MiRNA-424 Protects Against Permanent Focal Cerebral Ischemia Injury in Mice Involving Suppressing Microglia Activation. Stroke 2013, 44, 1706-1713. [CrossRef]

190. Wu, L.-N.; Hu, B.; Zhao, B.-T.; Liu, Y.-N.; Yang, Y.; Zhang, L.-J.; Chen, J.-F. Circulating microRNA-422a is associated with lymphatic metastasis in lung cancer. Oncotarget 2017, 8, 42173-42188. [CrossRef]

191. Kumar, K.; Trzybulska, D.; Tsatsanis, C.; Giwercman, A.; Almstrup, K. Identification of circulating small non-coding RNAs in relation to male subfertility and reproductive hormones. Mol. Cell. Endocrinol. 2019, 492, 110443. [CrossRef]

192. Chen, L.; Chen, R.; Kemper, S.; Cong, M.; You, H.; Brigstock, D.R. Therapeutic effects of serum extracellular vesicles in liver fibrosis. J. Extracell. Vesicles 2018, 7, 1461505. [CrossRef] 
193. Chen, L.; Yang, J.; Lü, J.; Cao, S.; Zhao, Q.; Yu, Z. Identification of aberrant circulating miRNAs in Parkinson's disease plasma samples. Brain Behav. 2018, 8, e00941. [CrossRef]

194. Assmann, T.S.; Riezu-Boj, J.I.; Milagro, F.I.; Martínez, J.A. Circulating adiposity-related microRNAs as predictors of the response to a low-fat diet in subjects with obesity. J. Cell. Mol. Med. 2020, 24, 2956-2967. [CrossRef] [PubMed]

195. Laengsri, V.; Kerdpin, U.; Plabplueng, C.; Treeratanapiboon, L.; Nuchnoi, P. Cervical Cancer Markers: Epigenetics and microRNAs. Lab. Med. 2018, 49, 97-111. [CrossRef] [PubMed]

196. Kiyosawa, N.; Watanabe, K.; Morishima, Y.; Yamashita, T.; Yagi, N.; Arita, T.; Otsuka, T.; Suzuki, S. Exploratory Analysis of Circulating miRNA Signatures in Atrial Fibrillation Patients Determining Potential Biomarkers to Support Decision-Making in Anticoagulation and Catheter Ablation. Int. J. Mol. Sci. 2020, 21, 2444. [CrossRef]

197. Moustafa, S.; Burn, M.; Mamillapalli, R.; Nematian, S.; Flores, V.; Taylor, H.S. Accurate diagnosis of endometriosis using serum microRNAs. Am. J. Obstet. Gynecol. 2020, 223, 557.e1-557.e1. [CrossRef] [PubMed]

198. Giordano, M.; Ciarambino, T.; D’Amico, M.; Trotta, M.C.; Di Sette, A.M.; Marfella, R.; Malatino, L.; Paolisso, G. Circulating MiR-NA-195-5p and -451a in Transient and Acute Ischemic Stroke Patients in an Emergency Department. J. Clin. Med. 2019, 8, 130. [CrossRef]

199. Zhang, L.; Chen, X.; Su, T.; Li, H.; Huang, Q.; Wu, D.; Yang, C.; Han, Z. Circulating miR-499 are novel and sensitive biomarker of acute myocardial infarction. J. Thorac. Dis. 2015, 7, 303-308. [CrossRef]

200. Alevizos, I.; Illei, G.G. MicroRNAs as biomarkers in rheumatic diseases. Nat. Rev. Rheumatol. 2010, 6, 391-398. [CrossRef]

201. Margolis, L.; Lessard, S.J.; Ezzyat, Y.; Fielding, R.A.; Rivas, D.A. Circulating MicroRNA Are Predictive of Aging and Acute Adaptive Response to Resistance Exercise in Men. J. Gerontol. Ser. A Boil. Sci. Med Sci. 2016, 72, 1319-1326. [CrossRef]

202. Roberts, T.C.; Blomberg, K.E.M.; McClorey, G.; EL Andaloussi, S.; Godfrey, C.; Betts, C.; Coursindel, T.; Gait, M.J.; Smith, C.I.E.; Wood, M.J. Expression Analysis in Multiple Muscle Groups and Serum Reveals Complexity in the MicroRNA Transcriptome of the mdx Mouse with Implications for Therapy. Mol. Ther. Nucleic Acids 2012, 1, e39. [CrossRef]

203. Lakhia, R.; Hajarnis, S.; Williams, D.; Aboudehen, K.; Yheskel, M.; Xing, C.; Hatley, M.E.; Torres, V.E.; Wallace, D.P.; Patel, V. Mi-croRNA-21 Aggravates Cyst Growth in a Model of Polycystic Kidney Disease. J. Am. Soc. Nephrol. 2016, 27, 2319-2330. [CrossRef]

204. McDonald, J.S.; Milosevic, D.; Reddi, H.V.; Grebe, S.K.; Algeciras-Schimnich, A. Analysis of circulating microRNA: Pre-analytical and analytical challenges. Clin. Chem. 2011, 57, 833-840. [CrossRef] [PubMed]

205. Wang, K.; Yuan, Y.; Cho, J.-H.; McClarty, S.; Baxter, D.; Galas, D.J. Comparing the MicroRNA Spectrum between Serum and Plasma. PLoS ONE 2012, 7, e41561. [CrossRef] [PubMed]

206. Moldovan, L.; Batte, K.E.; Trgovcich, J.; Wisler, J.; Marsh, C.B.; Piper, M. Methodological challenges in utilizing miRNAs as circu-lating biomarkers. J. Cell Mol. Med. 2014, 18, 371-390. [CrossRef] [PubMed]

207. Vigneron, N.; Meryet-Figuière, M.; Guttin, A.; Issartel, J.-P.; Lambert, B.; Briand, M.; Louis, M.-H.; Vernon, M.; LeBailly, P.; Lecluse, Y.; et al. Towards a new standardized method for circulating miRNAs profiling in clinical studies: Interest of the exogenous normalization to improve miRNA signature accuracy. Mol. Oncol. 2016, 10, 981-992. [CrossRef] [PubMed]

208. Wong, R.K.Y.; MacMahon, M.; Woodside, J.V.; Simpson, D.A. A comparison of RNA extraction and sequencing protocols for de-tection of small RNAs in plasma. BMC Genom. 2019, 20, 446. [CrossRef]

209. Kloten, V.; Neumann, M.H.D.; Di Pasquale, F.; Sprenger-Haussels, M.; Shaffer, J.M.; Schlumpberger, M.; Herdean, A.; Betsou, F.; Ammerlaan, W.; Af Hällström, T.; et al. Multicenter Evaluation of Circulating Plasma MicroRNA Extraction Technologies for the Development of Clinically Feasible Reverse Transcription Quantitative PCR and Next-Generation Se-quencing Analytical Work Flows. Clin. Chem. 2019, 65, 1132-1140. [CrossRef] [PubMed]

210. Perez-Gracia, J.L.; Sanmamed, M.F.; Bosch, A.; Patiño-García, A.; Schalper, K.A.; Segura, V.; Bellmunt, J.; Tabernero, J.; Sweeney, C.J.; Choueiri, T.K.; et al. Strategies to design clinical studies to identify predictive biomarkers in cancer research. Cancer Treat. Rev. 2017, 53, 79-97. [CrossRef]

211. Wang, Y.-N.; Yu, L.; Zhao, X.-S.; Zhang, W.; Wan, J.; Yu, B. Establishment of plasma microRNA detection method by using taqman probe based quantitative reverse transcription PCR. Cell. Mol. Boil. 2015, 61, 51-54.

212. Carlomosti, F.; D'Agostino, M.; Beji, S.; Torcinaro, A.; Rizzi, R.; Zaccagnini, G.; Maimone, B.; Di Stefano, V.; De Santa, F.; Cordisco, S.; et al. Oxidative Stress-Induced miR-200c Disrupts the Regulatory Loop Among SIRT1, FOXO1, and eNOS. Antioxid. Redox. Signal. 2017, 27, 328-344. [CrossRef] [PubMed]

213. Pagacz, K.; Kucharski, P.; Smyczynska, U.; Grabia, S.; Chowdhury, D.; Fendler, W. A systemic approach to screening highthroughput RT-qPCR data for a suitable set of reference circulating miRNAs. BMC Genom. 2020, 21, 111. [CrossRef] [PubMed]

214. Li, Y.; Kowdley, K.V. Method for microRNA isolation from clinical serum samples. Anal. Biochem. 2012, 431, 69-75. [CrossRef] [PubMed]

215. Zhang, C.; Xia, R.; Zhang, B.; Wang, H. The predictive powers of plasma trefoil factor 3 or its related micro RNAs for patients with hepatocellular carcinoma. BMC Cancer 2018, 18, 1-6. [CrossRef] [PubMed] 